\title{
Review of geology of the New Siberian Islands between the Laptev and the East Siberian Seas, North East Russia
}

\author{
M. Kos'ko ${ }^{1}$ and E. Korago ${ }^{2}$ \\ ${ }^{1}$ Geological Institute Russian Academy of Sciences, St.-Petersburg Laboratory for geology and mineralogy of polar areas, 1 , \\ Angliysky Prospekt, 190121, St.-Petersburg, Russia \\ ${ }^{2}$ VNIIOkeangeologia, 1, Angliysky Prospekt, 190121, St.-Petersburg, Russia
}

\begin{abstract}
The New Siberian Islands comprise De Long Islands, Anjou Islands, and Lyakhov Islands. Early Paleozoic, Mesozoic and Cenozoic sediments and igneous rocks are known on the De Long Islands. Cambrian slate, siltstone, mudstone and silicified limestone occur on Bennett Island. Ordovician volcanogenic turbidites, lavas, and small intrusions of andesite-basalt, basalt, dolerite, and porphyritic diorite were mapped on Henrietta Island. The igneous rocks are of calc-alkaline island arc series. The Ordovician age of the sequence was defined radiometrically. Early Paleozoic strata were faulted and folded presumably in the Caledonian time. Early Cretaceous sandstone and mudstone are known on Bennett Island. They are overlain by a 106-124 Ma basalt unit. Cenozoic volcanics are widespread on the De Long Islands. Zhokhov Island is an eroded stratovolcano. The volcanics are mostly of picrite-olivine type and limburgite. Radiometric dating indicates Miocene to Recent ages for Cenozoic volcanism.
\end{abstract}

On the Anjou islands Lower-Middle Paleozoic strata consist of carbonates, siliciclastics, and clay. A Northwestsoutheast syn-sedimentary facies zonation has been reconstructed. Upper Paleozoic strata are marine carbonate, clay and siliciclastic facies. Mudstone and clay predominate in the Triassic to Upper Jurassic section. Aptian-Albian coal bearing deposits uconformably overlap lower strata indicating Early Cretaceous tectonism. Upper Cretaceous units are mostly clay and siltstone with brown coal strata resting on Early Cretaceous weathered rhyolite. Cenozoic marine and nonmarine silisiclastics and clay rest upon the older units with a transgressive unconformity including a weathering profile in the older rocks.

Manifestations of Paleozoic and Triassic mafic and Cretaceous acidic magmatism are also found on these islands. The pre-Cretaceous structure of the Anjou islands is of a block

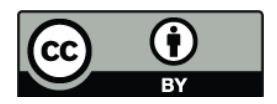

Correspondence to: M. Kos'ko (kosko@vniio.nw.ru) and fold type Late Cimmerian in age followed by faulting in Cenozoic time.

The Lyakhov islands are located at the western end of the Late Cimmerian South Anyui suture. Sequences of variable age, composition, and structural styles are known on the Lyakhov Islands. These include an ancient metamorphic sequence, Late Paleozoic ophiolitic sequence, Late Mesozoic turbidite sequence, Cretaceous granites, and Cenozoic sediments. Fold and thrust imbricate structures have been mapped on southern Bol'shoi Lyakhov Island. Northnorthwestern vergent thrusts transect the Island and project offshore. Open folds of Jurassic-Early Cretaceous strata are characteristic of Stolbovoi and Malyi Lyakhov islands.

Geology of the New Siberian Islands supports the concept of a circum Arctic Phanerozoic fold belt. The belt is comprised of Caledonian, Ellesmerian, Early Cimmerian and Late Cimmerian fold systems, manifested in many places on the mainland and on islands around the Arctic Ocean. Knowledge of the geology of the New Siberian Islands has been used to interpret anomalous gravity and magnetic field maps and Multi Channel Seismic (MCS) lines. Two distinguishing structural stages are universally recognized within the offshore sedimentary cover which correlate with the onshore geology of the New Siberian Islands. Dating of the upper structural stage and constituent seismic units is based on structural and stratigraphic relationships between Late Mesozoic and Cenozoic units in the archipelago. The Laptev Seawestern East Siberian Sea seismostratigraphic model for the upper structural stage has much in common with the seismostratigraphic model in the American Chukchi Sea.

\section{Introduction}

The New Siberian Islands (Fig. 1) are located between the Laptev Sea to the west and the East Siberian Sea to the east. The geological data from the islands has been projected offshore to help understand the poorly known sea bottom

Published by Copernicus Publications on behalf of the European Geosciences Union. 


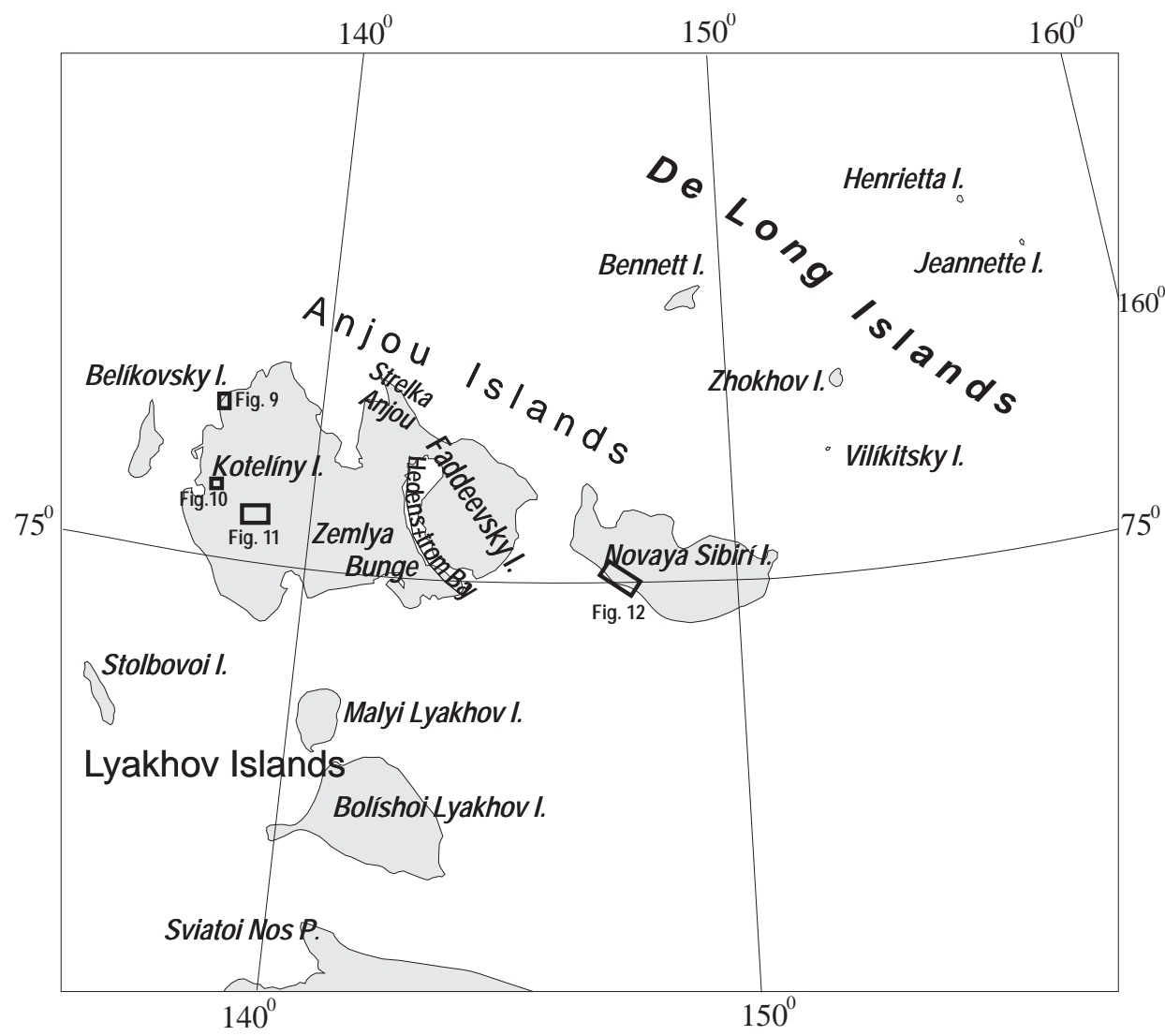

Fig. 1. New Siberian Islands. Location Map (note locations for Figs. 9, 10, 11, and 12).

geology. The East Siberian and Laptev seas are very large, and they have a major role to play in allowing us to understand the geologic history of the whole Arctic region, of which our knowledge is fragmentary. Building on the work done on the small parts that are above sea-level is critical to interpreting the offshore geology.

The present day knowledge of the geology of the islands is largely based on the results of multi-disciplinary research and exploration carried out under VNIIOkeangeologia and Polar Marine Geosurvey Expedition (PMGE) projects in the last century, in the 1970's and 1980's. Geoscientists from a number of the Russian Academy of Science institutes A. B. Kuzmichev, G. V. Flerov, S. A. Silantiev, O. G. Bogdanovsky, S. S. Drachev, Yu. P. Masurenkov, L. A. Savostin, P. I. Fedorov, and others have made significant contributions to the knowledge of the geology of the New Siberian Islands since that time.

There are many general and detailed publications in Russian and a few papers in English treating the archipelago as a whole or focused on individual islands and special problems. The review presented here is a brief up-to-date summary of available geological information. Some earlier models have been updated, new field and laboratory studies performed but the only dramatic revision concerns the stratified sequences and the tectonic structure of Bol'shoi Lyakhov Island.
The purpose of this paper is to provide an outline of the general geology of the archipelago and to indicate some Arctic and northeast Asian geoscientific problems for which knowledge of the geology of the New Siberian Islands can help provide solutions.

The New Siberian Islands comprise three constituent archipelagos: De Long Islands, Anjou Islands, and Lyakhov Islands. The archipelagos are extremely variable in magmatic and sedimentary sequences exposed and structural patterns. They are described below separately starting from the northern De Long Islands.

\section{The De Long Islands}

Early Paleozoic, Mesozoic and Cenozoic sediments and igneous rocks are known on the De Long Islands.

\subsection{Henrietta and Jeanette Islands}

Ordovician volcanogenic turbidites, lavas, and small intrusions have been mapped on Henrietta Island (Fig. 2). The sequence comprises four units: quartzite sandstone $(170 \mathrm{~m})$; rhythmic volcano-clastic mudstone and sandstone (more than $150 \mathrm{~m}$ ); volcano-clastic sandstone and gritstone with interlayers of siltstone, tuff, and basalt lava sheets $(370 \mathrm{~m})$. There 

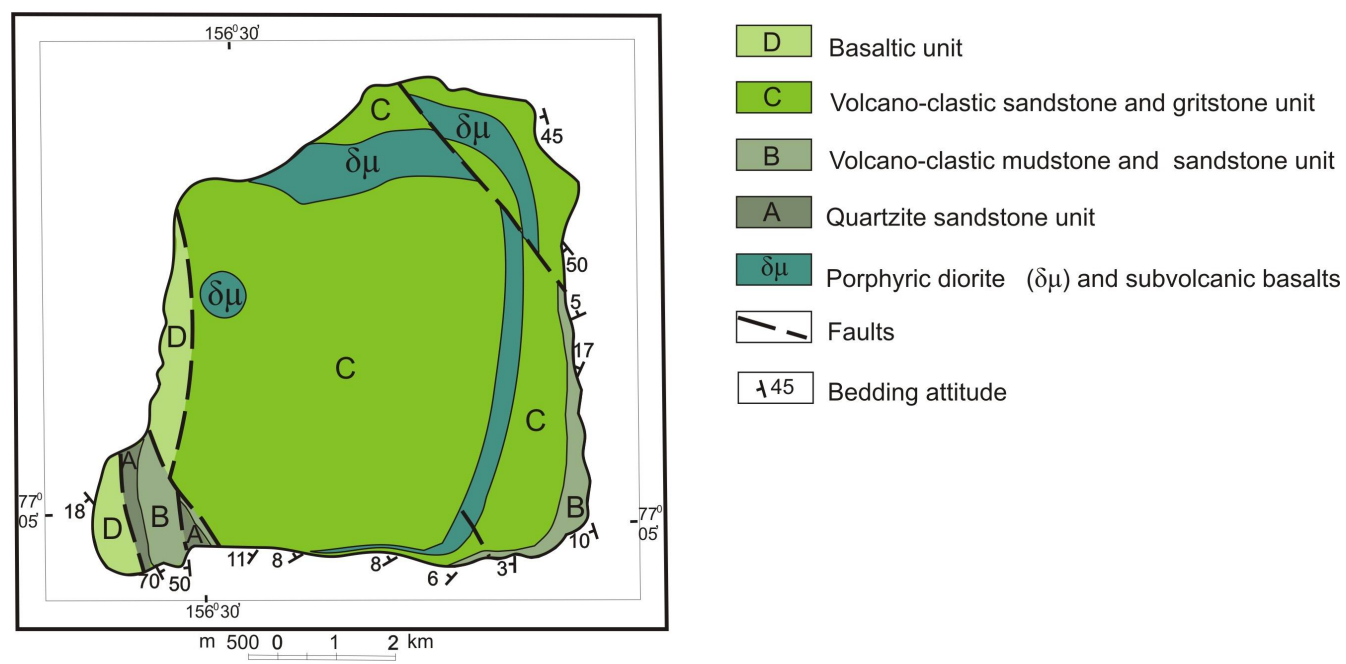

Fig. 2. Geological map of Henrietta Island. Simplified from Dorofeev et al. (1999).

is a hiatus at the base of this unit. The fourth is a basaltic unit $(160 \mathrm{~m})$ faulted against the others and thought to be the uppermost unit in the section. Numerous andesite-basalt, basalt, dolerite, and porphyritic diorite flows, sills and dykes are known on the island (Vinogradov et al., 1975). One more unit has been reported on the top of the stratified section on Henrietta Island by M. M. Ermolaev (Vol'nov et al., 1970) and which is not mentioned in Vinogradov's et al. (1975). The unit is composed mostly of well rounded pebbles of the underlying rocks and most likely has a disconformity at its base.

It is believed that the same sequence outcrops on Jeannette Island. The pebble and cobble unit here disconformably overlies graywacke and volcano-clastics similar to those on Henrietta Island. Pebbles and cobbles up to $70 \mathrm{~cm}$ in diameter are metamorphic rocks, granites and mafic volcanics (Vol'nov et al., 1970). These volcano-sedimentary rocks on the Jeannette Isl. dip ENE at $60^{\circ}$ (Vol'nov et al., 1970).

Henrietta Island is described by Vinogradov et al. (1975) as a part of the eastern flank of a wide syncline trending close to North. The steepest bedding is on the northeastern part of the island, where the beds dip to the west at an angle of $43^{\circ}-$ $45^{\circ}$. Tightly folded and faulted layers transiting into more horizontal bedding were observed to the south. On the east coast and in most of the south parts of the island, the beds dip to the northwest and to the west at $8^{\circ}-10^{\circ}$, leveling in some places up to $3^{\circ}-4^{\circ}$. In some places they dip slightly steeper at $15^{\circ}-17^{\circ}$. In the most southwestern part of the island a volcanogenic basaltic unit dips to the southwest at $5^{\circ}-20^{\circ}$. This southwestern part of the island is also separated from the rest of the island by a zone of intense deformation about $600 \mathrm{~m}$ wide with a sub-longtitudinal strike. Strike slip faults dipping to the east at an angle of $70^{\circ}-75^{\circ}$, together with low amplitude NW striking steep faults are present within the deformation zone. Separate box folds with steep limbs $\left(50^{\circ}-70^{\circ}\right)$, monoclines dipping at $70^{\circ}-80^{\circ}$, vertical layers, bundles of isoclinal folds $10-20 \mathrm{~m}$ wide with sub-horizontal and subvertical hinges have been reported (Vinogradov et al., 1975). Cleavage dipping from $80^{\circ}$ up to vertical is wide-spread. In the north of the island the strike of cleavage is close to NS. Two cleavage systems with strikes of $310^{\circ}-320^{\circ}$ and $45^{\circ}-$ $50^{\circ}$ are present on the south coast of the island.

The clasts in the rocks on Henrietta Island consist of schist, microcline granite, gneiss, micropegmatite, quartzite, rhyolite and dacite-andesite along with rocks similar to those of the flows, sills and dykes. The igneous rocks are typical of a calc-alkaline island arc (Fig. 3). The metamorphic grade is of green schist facies.

Whole rock argon-argon ages give $440 \mathrm{Ma}$ for a porphyritic diorite and $444 \pm 2 \mathrm{Ma}$ for a dolerite (Kaplan et al., 2001). Previous potassium-argon whole rock determinations indicated an Ordovician age along with younger ages: 450 , 310, 375, 430, $390 \mathrm{Ma}$ (Gramberg et al., 2004).

\subsection{Bennett, Zhokov and Vil'kitsky Islands}

Cambrian strata $500 \mathrm{~m}$ thick occur on Bennett Island (Vol'nov and Sorokov, 1961) consisting of dark-grey slate with thin interlayers of siltstone and silicified limestone. The lower half of the section contains Middle Cambrian trilobites. The upper portion of the section is composed of alternating siltstone and mudstone with interbeds of essentially quartz sandstone with Tremadocian and Arenigian (Lower Ordovician) graptolites (Vol'nov et al., 1970; Sobolevskaya, 1976). The section is capped by variegated quartz sandstone, provisionally assigned to the Ordovician. Early Cretaceous sandstone and carbonaceous mudstone $20 \mathrm{~m}$ thick are known on Bennett Island. They are overlain by an alkaline basalt unit built of lava sheets with thin lenses of tuffaceous mudstone. The mudstone contains spore and pollen characteristic 


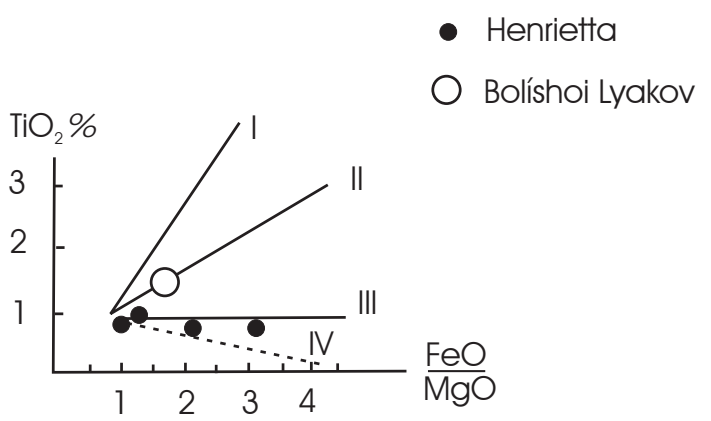

Fig. 3. Plots of $\mathrm{TiO}_{2} \%$ versus $\mathrm{FeO} / \mathrm{MgO}$ for early Paleozoic mafic rocks from Henrietta and Bol'shoi Lyakov islands (Miyashiro et al., 1970) and trends for basalts in various geodynamic settings: I- intraplate, II - middle oceanic, III - island arc, IV - calc-alkaline trend.

of the second half of the Early Cretaceous. The basalt unit is $360-500 \mathrm{~m}$ thick. Two volcanic cones composed of manganese alkaline basalt flows and volcano-clastics separated from the stratified lava unit have been mapped on the east coast of the island. The Potassium-Argon ages of the basalts are 119-112 $\pm 5 \mathrm{Ma}$ (Gramberg et al., 2004; Drachev, 1989 ) and $106 \pm 4,109 \pm 5,110 \pm 5,124 \pm 6 \mathrm{Ma}$ (Fedorov et al., 2005).

Cenozoic volcanics are widely spread on the De Long Islands. Zhokhov Island is an eroded stratovolcano. Sea cliffs are composed of alternating flows of massive and blister lava, agglomerate and tuff, variable in texture, structure, porosity, and color. Massive columnar channel fill basalts outcrop on the top. The slopes are covered with volcanic ash containing large volcanic bombs. Basalts are mostly of picrite-olivine type. Vilkitsky Island is built of limburgite. Minor amounts of limburgite were also reported from Zhokhov Island (Silantiev et al., 1991, 2004; Vol'nov et al., 1970). Fragments of mantle spinel lherzolite, quartzite, and aphyric volcanic rock are present in the volcanic breccia. Silicified Carboniferous limestone (Makeev et al., 1991), and perhaps dolerite, which has a different mineral composition and chemistry from the volcanics exposed on either of the islands, could be assigned to fragments brought up from depth, representing units not exposed on the surface. Potassium-argon ages for the dolerite are in the range 99$152 \mathrm{Ma}$ (Gramberg et al., 2004). Spinel lherzolite clasts in extrusive rocks on Zhokhov Island show ages of $545 \pm 106$, $605 \pm 47$ and $1110 \pm 57 \mathrm{Ma}$ (Silantyev et al., 2004).

Cenozoic volcanic rocks on the De Long Islands are of intraplate continental type. The depth of the magma source chamber exceeds $60 \mathrm{~km}$. The chemistry of the mantle inclusions and the lava flows indicates a depleted mantle origin (Bogdanovsky et al., 1992; Silantyev et al., 2004;.

Potassium-argon age determinations of basalts from Zhokhov Island give a range from 1.2 to $10 \mathrm{Ma}$ (Gramberg et al., 2004; Drachev, 1989; Bogdanovsky et al., 1992). The limburgite of Zhokhov Island gives a potassium-argon age of 1.88-4.21 Ma, and on Vil'kitsky Island an age of 0.4 $0.89 \mathrm{Ma}$. The Argon-Argon age of basalts from Zhokhov Island is $1.20 \pm 0.19 \mathrm{Ma}$ (Layer et al., 1992). Thus, volcanism commenced in Miocene and terminated in Recent time. Quaternary volcanic buildups have been described on the lava plateau on Bennett Island (Masurenkov and Flerov, 1989).

Both middle Cretaceous basalts on Bennett Island and Miocene to Recent basalts on Zokhov and Vil'kitsky islands were attributed to mantle plume activity (Silantyev et al., 2004).

Bennett Island is an erosional remnant of a lava plateau on the Early Paleozoic basement. Cambrian-Ordovician units forms a NNW trending anticline about $20 \mathrm{~km}$ wide within the limits of the island. Dip angles on the limbs are usually up to $10^{\circ}$, rarely up to $50^{\circ}$. The Late Mesozoic- Cenozoic strata were not folded. Inclined bedding of lavas is related to the prevolcanic topography (Vol'nov et al., 1970).

\section{The Anjou Islands}

The Anjou Islands are Bel'kovsky, Kotel'ny, Faddeya, and Novaya Sibir' Islands. They are situated on the margin of the Late Kimmerian (Late Jurassic-Early Cretaceous) fold and thrust belt of the Northeast Asia. Late Kimmerian deformations here are not as pronounced as those on the mainland, on the Lyakhov Islands, and on Wrangel Island.

\subsection{Stratified sequences}

\subsubsection{Paleozoic}

Deposits from Lower Ordovician to Recent time have been mapped on the Anjou Islands. The age of the map units and the correlation with the general stratigraphic scale are reliably supported by fossil identifications.

\section{Lower Ordovician-Middle Devonian}

Lower Ordovician-Middle Devonian units are composed of limestone, dolomite with minor siliciclastic, siliciclastic- and siliceous-carbonate deposits. Facies zonation and depositional settings for the Early-Middle Paleozoic have been reconstructed. (Kos'ko, 1977; Fig. 5). Deep water, shallow marine, lagoonal and local stagnant basin environments were recognized.

Deep water facies are fine grained, thin horizontally laminated limestone, dark colored siliceous-argillaceouscarbonate sediments with abundant plankton (plus graptolites in the Silurian and tentaculitids in the Devonian) and poor benthos, with pyrite dissemination and concretions. The depth of the basin is about $500 \mathrm{~m}$ for the Llandoverian. Shallow water deposits of the same age in the northeast facies zone have a thickness of $450 \mathrm{~m}$. The thickness of the synchronous graptolite facies in the southwest zone is $50 \mathrm{~m}$. The depth of the basin $(\approx 400 \mathrm{~m})$ is approximately the difference between the thicknesses of the deposits. 
Shallow water marine sediments vary in clast size from silt to breccia. Sedimentary structures characteristic of active hydrodynamics are typical. Benthic and less common nektonic fossils, wide distribution of the algal limestone, traces of detritovores, bioherms (Fig. 6), and accumulations of similarly orientated (convex upward) large brachiopods and bivalves, which indicates moderate bottom water turbulence, are characteristic of shallow marine sediments. Slump folds, and slump breccia are usual (Fig. 7). Mud cracks are quite common.

Coastal shallow water, and open shelf environments are distinguishable in the Late Ordovician based on differences in the faunal population. Near coast shallow water setting was confined to northeast Kotel'ny Island. Typical fossils here are tabulate and colonial rugosa corals along with various other benthos fossils. Biostromes built of various tabulate species are present. Traces of detritovores are abundant. Stromatoporas sometimes grow on tabulate corals. Shallow water mud shoals with bottom flow channels were reconstructed. Features of an open sea are well pronounced to the south and to the southwest. In the southwest of the island, accumulations of bryozoans, trilobites, ostracodes, brachiopods, and bivalves are typical. The coral assemblage is poorly developed here. Massive accumulations of large, excellently preserved, Pentamyridae shells, together with stromatoporas, are common.

Lagoonal environments are mainly represented by algal and bioclastic limestone and dolomite mixed with clay, silt, and sand. The color of the rocks is light grey, yellowish grey, yellow, and red. Layering is horizontal and inclined. Biogenic lamination, small ripple marks, and desiccation cracks are very common. Shelly layers were observed. Accumulations of the same type fossils - ostacodes, angarella, stromatoporoids, and rare occurrences of stenohaline fossils, are typical.

Local stagnant basin environments are suggested by marine sediments with features of active hydrodynamics and those deposited in nearly still waters (fine grained limestone, clayey limestone, and mudstone) are intertwined in the section and across the area.

Facies zonation in the Ordovician-Middle Devonian reflects the differentiation of vertical tectonic movements against the background of prevailing submergence. The northwestern strike of facies zones with deeper marine zones in the southwest is clearly pronounced in epochs of maximal differentiation of settings. The SW of Kotel'ny Island submerged more rapidly, than its NE part. At the beginning of the Middle Devonian general uplift was marked by hiatus over most of Kotel'ny Island and replacement of deep water environments by shallow water environments. In the Middle Devonian quite dissected relief existed which is attested to by slump structures, abundance of breccia, conglomeratebreccia, conglomerate, and diversity of facies.

\section{Upper Devonian-Lower Carboniferous}

In Late Devonian to Early Carboniferous time clastic deposits of marine, lagoonal and subareal origin prevailed (Fig. 8). In spite of uncertainty in constraining the erosion area in northeastern Kotel'ny Island, the NW strike of the facies zones is observable. Zonation is emphasized by the increase in size of clastic material also to the SE. Increase of the thickness of the Upper Devonian-Lower Carboniferous units in the SW is consistent with the facies pattern, and Bel'kovsky-Nerpalakh trough is identified here. For the inner part of the trough a continuous section of the Upper Devonian-Lower Carboniferous deposits is typical. The periphery of the trough is characterized by erosion and missing intervals. The trough inherits the area of the Ordovician to the Silurian major submergence (Kos'ko et al., 1985).

Mudstone, quartz and greywacke-quartz calcareous grey siltstone prevail in the marine environments. Limestone is less abundant. Organic build-ups accompanied by carbonate breccia, lenses and interbeds of carbonate conglomeratebreccia, together with interbeds of sandstone occur. The preservation of marine fossils varies from the whole shells to shell detritus.

Lagoonal (coastal) facies are represented by siltstone, mudstone and clay, sand and sandstone. The amount of carbonate layers is less than in marine environments, and the content of dolomite is higher. The color of the deposits is grey, purple-grey, purple, brown, and cherry- brown. Algal, organogenic-detrital oncolite limestones are common. The layering is undulatory and cross-laminated. Traces of detritovores, undulation ripples, clayey pebbles at the bottom of layers, and desiccation cracks are common. Plant fragments occur. Faunal assemblage is depleted, although the tidal accumulations of large fragments of brachiopods, bivalves, gastropods and crinoidea occur. Abundant remains of Frasnian fish are remarkable.

Nonmarine strata were found on the west coast of Kotel'ny Island. They are composed of red and variegated colored sandstone, sand, and siltstone with interlayers of dolomite, mudstone and clay, with large oblique and lenticular laminations, and erosional surfaces. Dispersed plant remnants are common. Apparently these are sub-aerial coastal sediments. Dark grey mudstone from the north of Kotel'ny Island is also confined to nonmarine environments. These strata do not contain marine fossils and are characterized by a rich complex of the Early Carboniferous miospores. Paleohydrochemical characteristics using the methods of Gramberg (1973) indicate the formation of the sediments in a fresh water setting.

\section{Middle to Upper Carboniferous}

These deposits are known on Bel'kovsky and Kotel'ny Islands, occurring as marine carbonate facies and clay and siliciclastic facies (Kos'ko et al., 1985). 
Marine carbonate facies are distributed in the center and in the northwest of Kotel'ny Island. These are shelly detritic limestone, grey, light grey, pink grey, quite often silty and arenaceous. Conglomerate with pebbles of dolomite, limestone, chert, quartz siltstones, and quartz with calcareous cement are present. The rocks are rich in foraminifera, bryozoa, brachiopods, less common nautiloids, and trilobites.

Clay and siliciclastic facies are distributed on the southwest of Kotel'ny Island. They are mudstone and sandstone with interlayers of calcareous conglomerates, limestone, and carbonaceous mudstone. A high content of dispersed carbonaceous plant fragments is typical. Siliciclastic rocks form packets $10-60 \mathrm{~m}$ thick. Thin interlayering of siltstone and sandstone or siltstone and mudstone are less common. The rocks are grey to black. Dolomite cherty and dolomite concretions are scattered across the unit. Sandstones are mainly fine grained, compositionally immature, unlike the mostly quartz sandstone of the underlying units. They are composed of quartz, predominantly acidic feldspar and rock clasts, including acidic and intermediate composition volcanics. Conglomerate breccias consist of fragments of limestone, cherty limestone and chert with calcareous cement. Limestones are shelly detritic, silicified and clayey. The lamination is thin oblique, lenticular, undulated, and horizontal with erosive surfaces. Fossils such as brachiopods, corals, foraminifera, bryozoans, crinoids, occur mainly in the lower part of the succession.

\section{Permian}

Permian sediments are known in the zone stretching from the northwest of Kotel'ny Island towards the center in a southeastern direction. They consist of mudstone, mudstonelike clay with interlayers of siltstone, sandstone, limestone, and rare siderite. Interlayers of sideritic pyritic and calcareous concretions occur. The color of the rocks is grey, light grey, black, and brown. Siltstones are polymictic and feldspathic quartz clayey, dolomitic, calcareous and arenaceous. Limestone are organic detrital and algal, thin laminated, and with terrigenous admixture. The layering is thin undulatory, lenticular, with tracks of detritovores, with intralayer erosion. Dispersed plant fragments and mineralized wood were observed. The fossils are various brachiopods, lingulids, bivalves, gastropods, foraminifera. In the northwest of the island siltstone and mudstone prevail. Towards the center they are replaced by clayey limestone and calcareous mudstone. Permian deposits accumulated in a near-shore shallow marine setting.

\subsubsection{Mesozoic}

\section{Lower-Middle Triassic}

These deposits are found in the northwest and in the center of Kotel'ny Island (Kos'ko et al., 1985). Mudstone and hydromuscovite clay, grey, dark grey, black and brown in color with chlorite and other clay minerals predominate in the section. Clay with volcanic glass and perhaps tufogenic montmorillonite clay together with interlayers of tuffaceous siltstone with glauconite, occur in the Induan (Lowermost Triassic) strata. Isolated basalt bodies are assigned to the Induan. Algal and detrital-algal limestone in layers up to $10 \mathrm{~m}$ thick within packets of alternating clay and marl are characteristic of the Lower Olenekian (Lower Triassic). They are quite rare at other stratigraphic levels, and their thickness does not exceed $0.7 \mathrm{~m}$. The Lower Triassic contains interlayers of siderite, quite often with gypsum. Carbonate packets contain interlayers and veins of gypsum. Phosphate, pyrite, marcasite, and siderite concretions are common. Bedding is thin and horizontal. Traces of detritovores and soft sediment slump structures occur. Fossils are abundant and diverse. Beds rich and barren of fossils alternate. Bivalves and ammonoides dominate in the fossil collections. Brachiopod, belemnite and echinoderm fragments are subordinate. Fragments of fish and reptiles occur. Foraminifera are abundant. Fragments of mineralized wood are mainly confined to the upper part of the section.

Sediments were accumulated in shallow water basins with varying salinity. Extremely high salinity is documented by gypsum containing clay with interlayers of dolomite and siderite. The paleoenvironment in northwestern Kotel'ny Island was more distant from the shoreline than that in the center.

\section{Upper Triassic}

Upper Triassic sediments are distributed in the same areas as the Lower-Middle Triassic as well as in the far south of Kotel'ny Island. The Upper Triassic strata are mainly mudstone, mudstone-like and clay of dark grey and black, and sometimes brown color. Interlayers of siderite and limestone occur. Limestones are detrital, algal and algaldetrital. Interlayers of crinoid limestone with well preserved whole sea lilies are typical. Interlayers of arenaceous siltstone occur in the upper part of the section. Sideritic, pyritic carbonate-phosphate concretions are abundant. Some interlayers contain scattered pyrite. Soft sediment slump structures and traces of detritovores occur. Fauna include foraminifera, bivalves, ammonoids, nautiloids, brachiopods, and reptilia. The sediments also contain a rich spore and pollen complex, mineralized wood, and cyanophiceae remnants (Kos'ko et al., 1985).

In the Carnian deposits, from the northwest coast towards the center of the island, the content of gypsum increases and significant quantities of algal limestone occur. In the south of the island clay deposits are absent, rocks are lithified and schistose. In the northwest of the island sediments accumulated in a marine basin with normal salinity. In the center of the island the salinity varied. In the Late Triassic as well as in the Early and the Middle Triassic an open sea setting occupied the northwest. 


\section{Jurassic deposits}

Lower Jurassic deposits are widely distributed in the center of Kotel'ny Island. The Middle and the Upper Jurassic have been penetrated by boreholes in different places in the Anjou Islands (Trufanov et al., 1986). The deposits are represented by grey, black and brown mudstone, silty mudstone and argillite-like clay. Grey and green-grey siltstone and fine grained sandstone increase up section. Siltstone and sandstone are compositionally immature with clayey, siderite and calcareous cement. Glauconitic sandstones with argillaceous and clayey-siderite pebbles occur. Sandstone and siltstone form interbeds and lenses from $2-8 \mathrm{~cm}$ to $50 \mathrm{~cm}$ thick. Interbeds of siderite and limestone are present. Siderite, phosphate and pyrite concretions are common. The lamination is massive or thin, horizontal, undulated and lenticular. Ripple marks, desiccation cracks, and traces of detritovores are common. The faunal complexity is significantly poorer than in the Triassic and includes bivalve, foraminifera, fragments of sea lilies, ammonoides, bones of reptiles, fragments of mineralized wood and plants fragments. The environment was a shallow water basin with normal and varying salinity; a coastal zone.

\section{Cretaceous}

\section{Neocomian}

A borehole on Zemlya Bunge contained clayey siltstone and sandstone with pebbles of basic lava. These are marine deposits with fragments of ammonoids, brachiopods, bivalves, gastropods, and with foraminifera.

\section{Aptian-Albian}

The coal bearing Balyktakhskaya formation of AptianAlbian age has been mapped on Kotel'ny Island, Zemlya Bunge, and Faddeevsky Island (Kos'ko et al., 1985; Trufanov et al., 1986). In the central part of Kotel'ny Island they fill synclines disturbed by faults and overlap lower sediments with angular unconformity. The thickness of the deposits reaches $500 \mathrm{~m}$ in a composite section. Deposits are clay, clayey siltstone, sandstone and sand, alternating with conglomerates, acidic tuffs and tuffaceous sandstone and beds of coal up to $25 \mathrm{~m}$ thick. They are capped by $60 \mathrm{~m}$ thick cover of rhyolite. Siderite and calcareous-clay concretions are common. Silty clay at the base of the unit contains angular fragments, pebbles and boulders of Paleozoic and Mesozoic rocks with identifiable fossils. The age was determined by identification of plants and spores and pollen complexes.

\section{Upper Cretaceous}

Upper Cretaceous deposits outcrop and were penetrated by boreholes in many places on Zemlya Bunge, on Faddeevskyi and Novaya Sibir' islands (Trufanov et al., 1986; Kos'ko et al., 1985; Lopatin, 1999; Kos'ko and Trufanov, 2002). Total thickness of the strata is $300 \mathrm{~m}$. The base of the Upper Cretaceous was penetrated by drilling in the center of Faddeevsky Island. The sediments rest horizontally on the Early Cretaceous rhyolite. The rhyolite was weathered and fragmented into debris and clay grus. The unit is composed of clay and siltstone with beds and interbeds of sand, sandstone, gravel, pebbles and brown coal. The thickness of clay and siltstone beds is from $2.5 \mathrm{~m}$ to $16 \mathrm{~m}$. Some clay beds consist of montmorillonite. Remains of wood roots occur in clay on the contact with the beds of brown coal. Sand and sandstone form beds from 0.2 to $7 \mathrm{~m}$ thick. Tuffaceous sand and sandstone were reported. The beds of brown coal reach $7 \mathrm{~m}$ in thickness. Plant remains consist of leaf prints, fragments of wood and the whole stems. Remains of the roots and the abundance of stems undoubtedly point to the autochthonous nature of the coal and indicate an onland, perhaps mangrove, paleoenvironment. Acidic volcanics and quartz predominate among pebbles; sandstone and mafic volcanics are rare. A Cenomanian-Turonian and maybe Coniacian age was determined on leaf prints and palynology.

\subsubsection{Cenozoic}

The Cenozoic sequence rests upon all the older units transgressively with an unconformity and a weathering profile at the base.

\section{Paleocene-Eocene}

These rocks occur in outcrops and drillholes on Zemlya Bunge, in the northern and central Faddeevskyi Island, and Novaya Sibir' Island. They are mainly onshore clay and silt with interlayers of sand and brown coal. The thickness of the unit reaches $90 \mathrm{~m}$. Eocene marine beds were found on the west coast of Kotel'ny Island. They are light grey sand with clay interlayers, and with ripple marks. Phytoplankton, foraminifera and marine diatoms give evidence for an Early Eocene age (Lopatin, 1999; Kos'ko and Trufanov, 2002).

\section{Upper Oligocene-Miocene}

These sediments are siliciclastic, coastal marine and onshore, with interlayers of brown coal (Kos'ko et al., 1985; Lopatin, 1999; Kos'ko and Trufanov, 2002) The sediments are sands with interlayers and beds of clay and silt, pebble beds, brown coal of $0.1-0.4 \mathrm{~m}$, rarely up to $3.5 \mathrm{~m}$ thick on Kotel'ny and Bel'kovsky islands. Coalified plant fragments are abundant. The unit rests transgressively on Devonian, Carboniferous and Paleocene-Eocene deposits.

Upper Oligocene-Miocene deposits form a continuous cover overlapping the older units with a hiatus at the base on Faddeyeevsky and Novaya Sibir' Islands. The unit consists of sand with subordinate silt, and clay with discontinuous layers of gravel and pebbles. Sparse fragments of brown 
coal, coalified wood, pebbles and boulders are typical. Pebbles and boulders are rhyolite, basalt, dolomite, limestone, siltstone, sandstone, quartz, chert. Carbonate pebbles are absent in the underlying Paleocene-Eocene unit, thus pointing to a new source area with outcropping sediments similar to those composing Kotel'ny Island. Leaf prints, lagoonal, marsh and lacustrine diatoms, fresh water ostracods, sea mollusks, estuarial microfossils were collected and identified. The sediments were formed in the coastal fluvial-lacustrine plain and tidal shallow water paleoenvironment. Fluvial facies are mainly confined to the Miocene interval. The thickness varies from $9 \mathrm{~m}$ on Kotel'ny Island to $190 \mathrm{~m}$ on the Eastern islands.

Upper Oligocene-Miocene deposits are more wide spread than the Paleocene-Eocene. They transgressively overlap all older formations with erosion on the contact with the Eocene. Marine deposits here are more widely distributed than in the Eocene, indicating the occurrence of a new terrestrial source area.

\section{Pliocene-Eopleistocene}

Deposits of this age are widely distributed across the whole of the Archipelago (Kos'ko et al., 1985; Lopatin, 1999; Kos'ko and Trufanov, 2002). They erosionally overly the Late Oligocene-Miocene strata on western Kotel'ny and Bel'kovsky Islands. The sediments here are sand, silt, pebbles, grus, and clay. Mud, silt, and sand with lenses of peat and scattered pebbles and angular fragments of local rocks dominate on Faddeevsky and Novaya Sibir' islands. Marine bivalve and marine and fresh water diatoms were recorded. The thickness ranges from $5 \mathrm{~m}$ on the western islands to $75 \mathrm{~m}$ on Novaya Sibir' Island. The unit was formed on a coastal fluvial-lacustrine plane and in a coastal marine shallow water setting.

\subsection{Magmatism}

Manifestations of Paleozoic and Mesozoic magmatism are found in the Anjou Islands. Small basic bodies and dikes seen mainly on southwestern Kotel'ny Island are assigned to the Middle-Late Paleozoic. According to airborne surveys, mafic bodies are present in the adjacent offshore. Stocks reach $0.9 \mathrm{~km}$ in size, dikes are traced up to $7 \mathrm{~km}$ with the thickness of 1-30 m. Intrusions are composed of dolerite, gabbro-dolerite, sometimes quartz bearing and olivine bearing, with rare gabbro-syenite schlieren. The intrusions are hosted by units up to the Upper Devonian. They are mainly confined to the Late Devonian-Early Carboniferous Bel'kovsky-Nerpalakh trough - Nerpalakh synclinorium in the present day structure (Figs. 4 and 8). Most of the rocks corresponds to MORB tholeiite in chemistry, and are close to the boundary with intraplate tholeiite, or (by other characteristics) to continental gabbro.

On Bel'kovsky Island magmatic rocks are subvolcanic tholeiites (Kuzmichev and Goldyrev, 2007;). They form vari- able bodies: dikes, small stocks, rare sills, and irregular bodies built of breccia and peperite. Volcanic bodies are lined up along the west coast of the island. Magmatism is dated at the Permian-Triassic boundary, 252 $\pm 5 \mathrm{Ma}$ (biotite from olivine gabbro-diabase stock, K-Ar determination (Kuzmichev and Goldyrev, 2007). Magmatism is comparable with traps of the Siberian Platform by age, mineral composition, and chemistry. On Bel'kovsky Island, in the upper part of the sedimentary host rocks magma intruded into semifluid water-rich substrate close to the surface. Such extrusions are somewhat later or simultaneous with sedimentation. This suggests that on Bel'kovsky Island Permian, and perhaps Triassic deposits were not lithified at the time of the mafic lava intrusion. A study by Kuzmichev and Goldyrev (2007) is an important contribution to the magmatic geology of the Anjou Islands and it is in agreement with the data on the Early Triassic volcanism on Kotel'ny Island.

At the base of the Lower Triassic on Kotel'ny Island, montmorillonite clay and clayey sediments with rare fragments of volcanic glass and tuffaceous siltstone are present. Close to the Triassic-Paleozoic contact in the center of the island blocks of basalts were studied and assigned to the Triassic based on identification of traces of volcanism in the composition of the sediments. Rare dolerite dikes occur among Triassic strata. The dolerite is slightly enriched in alkalies and it differs from the Paleozoic mafics having less alteration. It also has a considerably stronger magnetization than is commonly seen in Paleozoic mafics (Gusev and Rakhin, 1977)

A rhyolite sheet and acidic tuffs in the upper part of the Early Cretaceous Balyktakhskaya formation on Kotel'ny, Faddeevskyi, and Zemlya Bunge Islands has been reported. Volcanism continued in the Late Cretaceous, which is evidenced by the presence of thin volcanic clastics in Cenomanian and Turonian strata.

\subsection{Structural geology}

The western Anjou Islands have the structure of a fold and thrust belt. It is characterized by a combination of folds of different orders and faults of two generations. The faults of the earlier generation strike northwest parallel to folds. They are normal and thrust faults probably with a strike-slip component. The faults of the later generation are normal faults and strike-slip faults trending north-south. The Reshetnikov and Chokur anticlinoria and the Balyktakh and Nerpalakh synclinoria are first order folds (Fig. 4). Anticlinoria are distinguished by an area of exposed Ordovician, Silurian and Lower Devonian strata. Synclinoria comprise widespread deposits from the Lower and Middle Devonian to the Mesozoic. Early Cretaceous strata are developed in the hinge of the Balyktakh Synclinorium. Deposits with the ages down to the Ordovician outcrop in the cores of the second order anticlines. The width of the anticlinoria and synclinoria is up to $50 \mathrm{~km}$. Their length reaches $150 \mathrm{~km}$. 
Second order folds (Figs. 10 and 11) are 10-40 km long and $5-12 \mathrm{~km}$ wide. Crest-like and block folds were recognized. The dip angles on the limbs of the second order folds vary from $10-30^{\circ}$ to $20-40^{\circ}$. Monoclines with dips of $3^{\circ}$ to $5^{\circ}$ which can be traced through many kilometers in coastal outcrops (Fig. 9) are common. Second order folds have undulated hinges with dip angles up to $30^{\circ}$.

Folds of the higher order are developed in zones of major faults. Folds are variable in geometry; tight and gentle, symmetric and asymmetric, concentric and others, variably oriented in some cases with steep hinges and limbs dipping up to $80^{\circ}$.

Anticlinoria and synclinoria inherited the synsedimentary tectonic zonation. The Reshetnikov Anticlinorium on northeast Kotel'ny Island coincides with a structural high in Llandovian-Early Ludlovian time. Its southwest flank is located on a Silurian synsedimentary flexure. The Bel'kovskyNerpalakh synclinorium on southwest Kotel'ny Island is a present day structural manifestation of the Late DevonianEarly Carboniferous Bel'kovsky-Nerpalakh trough.

The age of folding is post Late Jurassic-pre Aptian. It is evidenced by the structural unconformity at the base of the Aptian-Albian Balyktakh formation. This folding masks previous tectonic deformations. The Early Cretaceous structure was affected by Cenozoic normal faults and dextral strike slip faulting.

The Early Cretaceous structure was formed as a result of northeast directed compression. Rigid northwest elongated basement blocks were separated from the underlying sequence by deep seated faults and shifted a little towards the north-east. The shifting was accompanied by northeast vergent thrust faults along with moderate folding and tilting of the Phanerozoic sedimentary cover within the blocks. Deformation along block boundaries was much more intense, complex folding developed accompanied by cleavage and small amplitude thrusting. Large thrust faults are visible on the geologic map (Fig. 4). The strike-slip motion along the boundaries of the blocks is indicated by en echelon offsets of the second order folds and their oblique orientation with respect to the general structural trend. It is also indicated by vertical dipping of minor fold hinges in a number of cases. The structure of Kotel'ny Island is significantly different from the fold and fold-overthrust and nappe type structure of Wrangel Island, of Bol'shoi Lyakhov Island and of the Anyui zone in Chukotka. It is more similar to the structural style of a number of regions of Verkhoyansk belt and Lena delta (Egorov and Surmilova, 2001; Prokopiev et al., 2001).

Eastern Faddevsky and Novaya Sibir' islands are separated from Zemlya Bunge by Hedenstrom Bay. It is believed that the bay coincides with a fault zone manifested in gradients of anomalous gravity and/or magnetic fields (Trufanov et al., 1986). Faddeevsky and Novaya Sibir' islands are nearly completely overlain by a loose Cenozoic cover. There are only few outcrops of the Cretaceous deposits. Jurassic sediments and Cretaceous volcanics have been penetrated by

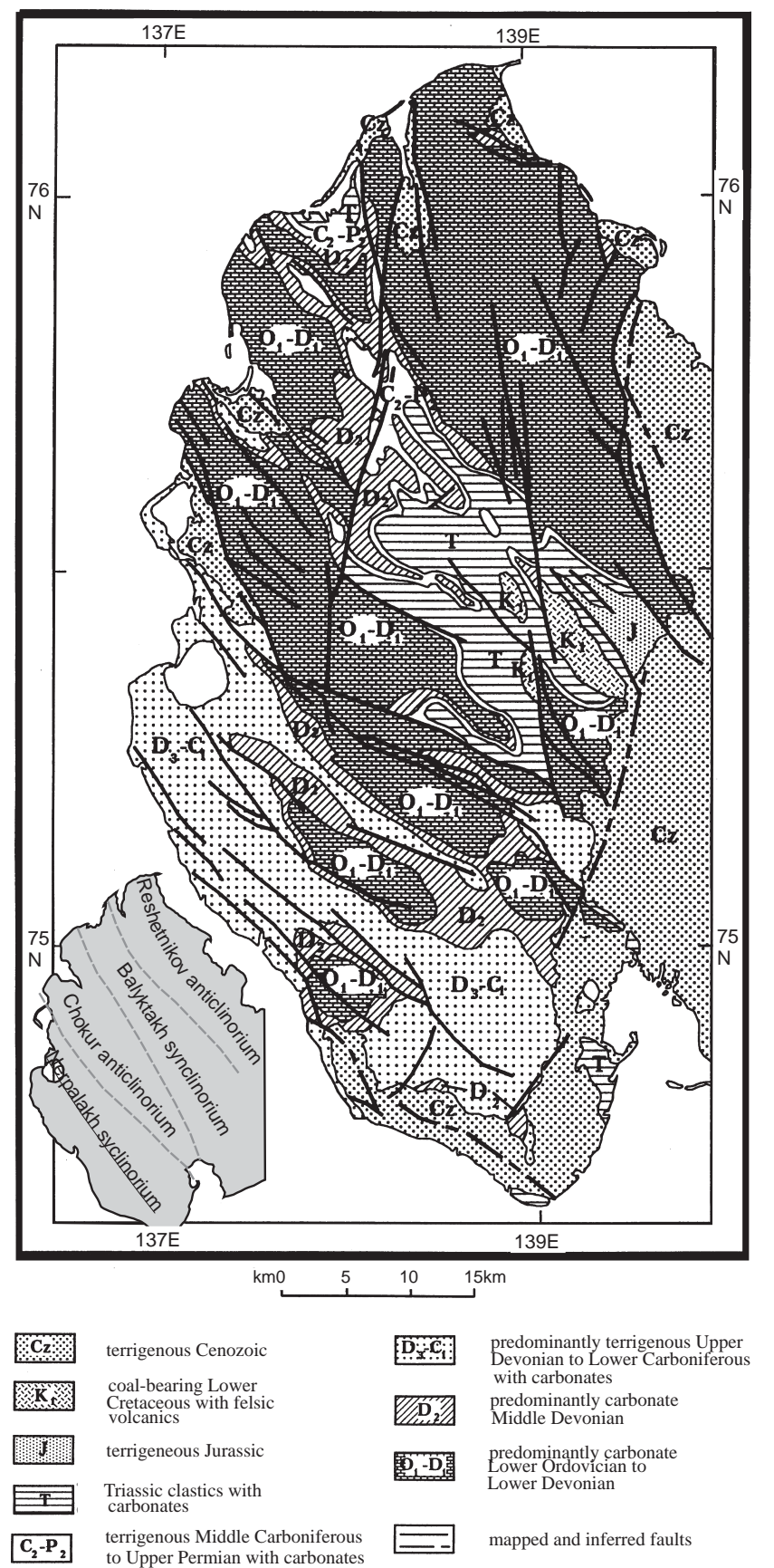

Fig. 4. Geological map and tectonic zonation of Kotel'ny Island.

test boreholes. Faults dominate in the structure of the sedimentary cover here. Most of them are not exposed due to the wide distribution of the Quaternary sediments, and have been mapped by geomorphologic and magnetic and/or gravity potential field data. The eastwest-northwest striking faults are the best defined. The length of these faults exceeds hundreds of kilometers and they project offshore. The distance between faults varies from 5 to $30 \mathrm{~km}$. They are displaced by submeridional wrench faults up to $15-20 \mathrm{~km}$ long. 


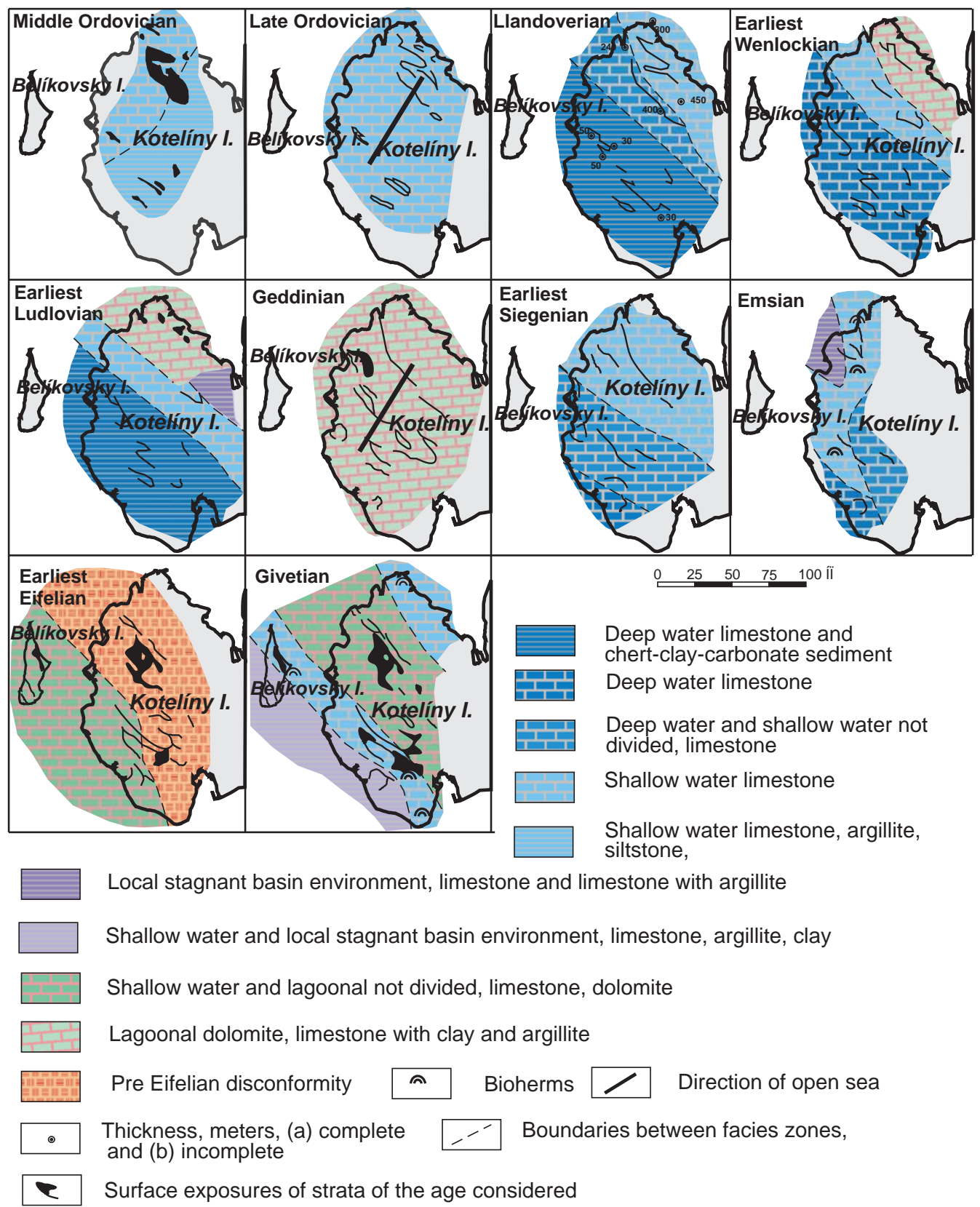

Fig. 5. Ordovician-Middle Devonian facies zonation (adapted from Kos'ko, 1977).

Large scale faults are accompanied by zones of folds. One of these was mapped from Strelka Anjou in the west eastwards along the north coast of Novaya Sibir' Island. Paleocene and Miocene strata form a row of en-echelon folds striking northwest. Limbs dip up to $40^{\circ}$. Complex folds and faults were mapped and observed in outcrops on Cape Vysoky and Cape Goristy, on northern Novaya Sibir' Island (Trufanov et al., 1986; Kos'ko and Trufanov, 2002).
Intense deformations were mapped in a belt apparently $2 \mathrm{~km}$ wide along the southwest of the Novaya Sibir' Island at Cape Utes Derevyannykh Gor (Fig. 12). The Late Cretaceous, Tertiary, and up to Pliocene strata form a fold and overthrust structure striking west-northwest. Trusts dipping north-northeast at $40-70^{\circ}$ are spaced at $50-600 \mathrm{~m}$ across the zone. Folds parallel the faults and are inclined southward. The north limbs of the anticlines dip north at angles $30^{\circ}-55^{\circ}$, the south limbs are vertical or overturned and quite often cut off. Recumbent folds are present. The length of larger folds 


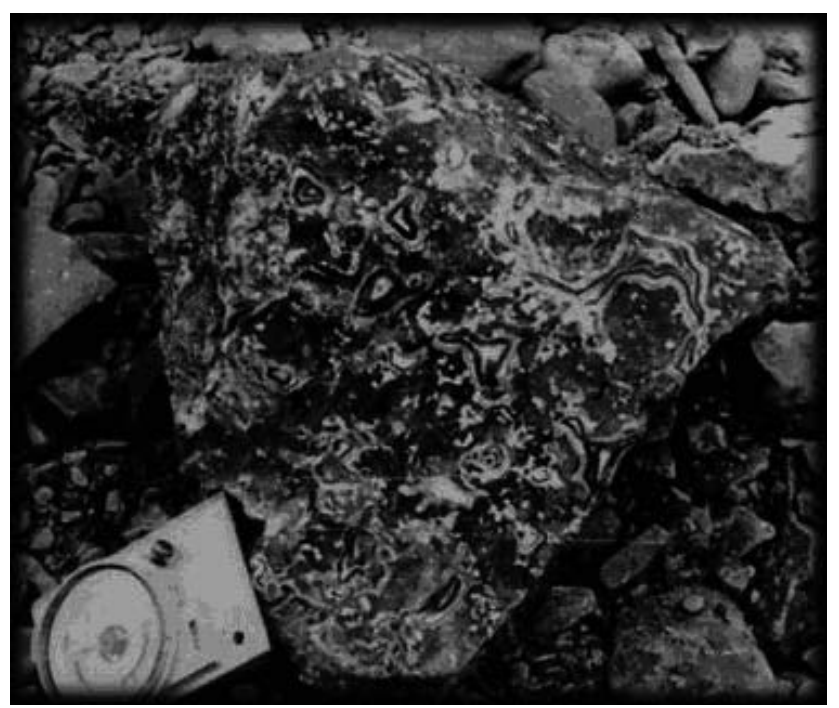

Fig. 6. Bioherm limestone. Givetian strata. Kotel'ny Island.

exceeds $4 \mathrm{~km}$ with the width from 100 to $250 \mathrm{~m}$. The length of small folds is not greater than a few hundred $\mathrm{m}$. Their width ranges from a few $m$ to a few tens of $m$. The amplitude of folds is from a few $\mathrm{m}$ up to $40-70 \mathrm{~m}$.

\section{Lyakhov islands}

The Lyakhov Islands are located at the western end of the South Anyui suture (Sokolov et al., 2002). Sequences of variable age, composition, and structural styles are known on the Lyakhov Islands. These include an ancient metamorphic sequence, Late Paleozoic ophiolitic sequence, Late Mesozoic turbidite sequence, Cretaceous granites, and Cenozoic sediments (Fig. 13)

\subsection{Metamorphic, magmatic and stratified sequences}

\section{The metamorphic sequence}

The oldest sequence on the Lyakhov Islands comprises amphibolite and schist of the epidote-amphibolite regional metamorphic facies (Samusin and Belousov, 1985; Lopatin, 1999; Drachev and Savostin, 1993). The rocks constitute a tectonic thrust sheet on southeastern Bol'shoi Lyakhov Island. Epidote, zoisite-epidote, pyroxene, plagioclaseamphibole, muscovite-amphibole, and garnet bearing amphibolite and schist were identified. Relict ophitic and vesicular textures were recognized in the metamorphic rocks. Pyroxene amphibolite is probably a product of metamorphism of a pyroxenite based on the relic structure (Lopatin, 1999). The initial igneous origin of the metamorphic rocks is supported by their chemistry as it is seen on the Miyasiro and Shido diagram (Fig. 3) and on more plots published recently (Gramberg et al., 2004). There are indications of the ophiolitic affinity of the initial igneous rocks.

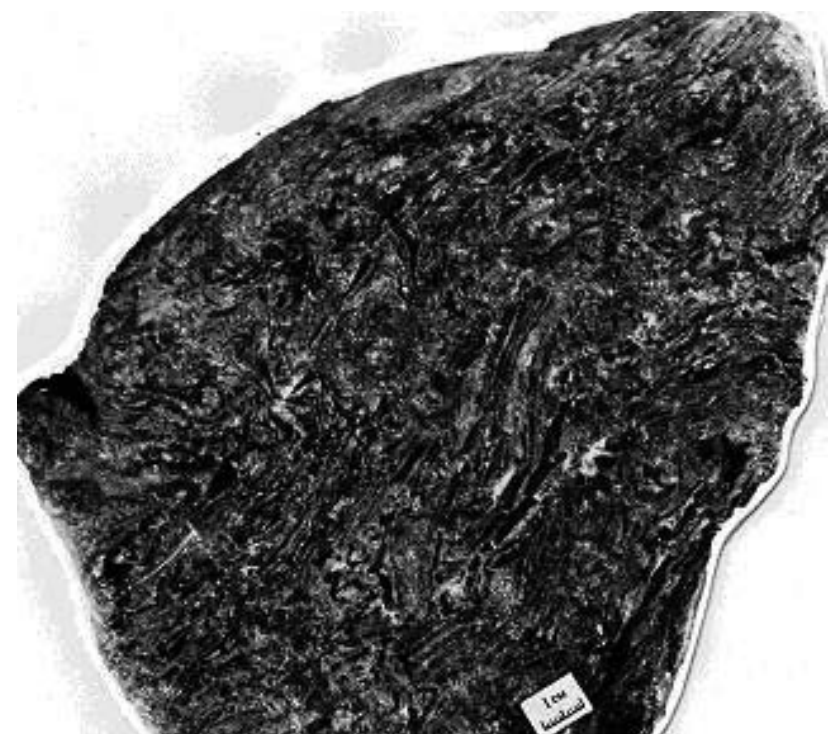

Fig. 7. Slump breccia, middle Devonian, Kotel'ny Island.

Whole rock K-Ar dating of the orthoamphibolites shows large differences in the ages: $473 \pm 14 \mathrm{Ma}, 215 \pm 8 \mathrm{Ma}$, and $166 \pm 7 \mathrm{Ma}$ (Drachev and Savostin, 1993). The oldest date is Caledonian, which is believed to be the age of the primary igneous rocks, while younger dates show some later alterations.

\section{Late Paleozoic ophiolites}

The Late Paleozoic ophiolitic sequence comprises ultramafic rocks, gabbro-dolerite, pillow basalt, hyaloclastite (Drachev and Savostin, 1993; Lopatin, 1999; Kuzmichev et al., 2005). Dunite, peridotite, and serpentinite form tectonic sheets along with basalt and gabbro-dolerite hosted by Late Mesozoic flysch on southeast Bol'shoi Lyakhov Island. Dunite is a fine grained massive rock composed of forsterite, serpentine, iddingsite, and secondary talc, muscovite, flogopite, tremolite, and ore minerals. The peridotite is a massive and schistose rock with rare forsterite phenocrysts and a groundmass of olivine, diopside, relics of rhombic pyroxene, secondary and accessory minerals. Serpentinite is widespread. Based on their chemistry the ultramafic rocks are metamorphosed ophiolite. Ultramafic and mafic bodies have high magnetization and are mappable offshore in accordance with the pattern of anomalous magnetic field maps (Lopatin, 1999).

Vesicular basalt, gabbro-dolerite and orthoamphibolite were found within the ultramafic rocks. Gabbro-dolerite bodies are up to $1000 \mathrm{~m}^{2}$ and veinlets up to $5 \mathrm{~cm}$ thick in the ultramafic rocks. The gabbro-dolerite is small-grained massive rock with ophitic groundmass and rare monocline pyroxene phenocrysts. The mafic rocks show the chemistry usual for the MORB basalt (Kuzmichev et al., 2005). 


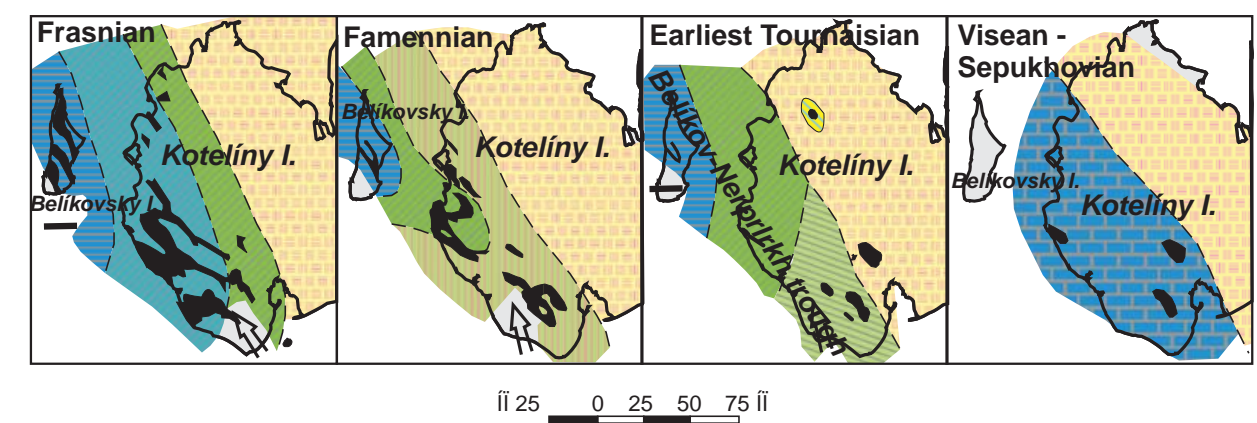

Marine environment argillite and siltstone with limestone, rare conglomerate and sandstone Marine environment limestone, siltstone argillite, rare conglomerate

Lagoonal and marine not divided, argillite, siltstone with sandstone,limestone, dolomite

Lagoonal argillite, siltstone, clay, sandstone, sand with limestone, dolomite, gritstone Lagoonal and continental not divided sandstone, sand, siltstone with argillite, clay, conglomerate, limestone and dolomite

Near shore plain sandstone, sand, siltstone with dolomite, argillite clay

Fresh water argillite

The main direction of the clastic flow

Boundaries between facies zones
Erosion

Subordinate direction of clastic flow

Surface exposures of strata of the age considered

Fig. 8. The Late Devonian Early Carboniferous facies zonation.

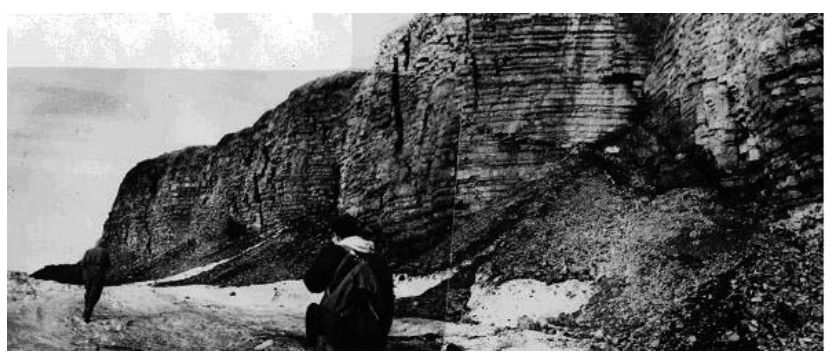

Fig. 9. Flat dipping of Lower and Middle Devonian strata. Chokur anticlinorium. Northwest coast of Kotel'ny Island. See location on Fig. 1.

A thrust sheet composed of pillow basalt is a part of a thrust sheet package that includes ultramafic rocks on southeastern Bol'shoi Lyakhov Island. The pillow basalt sheet is no less than $200 \mathrm{~m}$ thick. The basalt is hard, vitreous, aphyric, and porphyritic with olivine and plagioclase phenocrysts. The basalt was subjected to green schist alteration. The basalt relates to the sodium tholeiite series. All the plots on the Mullen diagram (Mullen, 1983) are inside the MORB and marginal seas area (Fig. 14). A tight cluster on the Pearce diagram (Pearce and Cann, 1973; Lopatin, 1999) lies close to the boundary between the MORB field, ocean islands field and continental rift field, most plots inside the latter (Fig. 15)

Sm-Nd age of the basalts is $291 \pm 62 \mathrm{Ma}$ according to Drachev and Savostin (1993). Kuzmichev et al. (2005) published $133.5 \pm 4.5$ and $139 \pm 8 \mathrm{Ma} \mathrm{K}-\mathrm{Ar}$ dating of the hyaloclastite separating the basalt pillows and admit their being skeptical whether both results are attributable to the age of the extrusions. Nevertheless both ages are compatible with the presence of Late Paleozoic as well as Late Mesozoic basalts within the South Anyui Suture in Chukotka which extends to Bol'shoi Lyakhov Island.

The mafic rocks were unevenly metamorphosed which resulted in the emplacement of various amphibolites and blue schist.

\section{Late Jurassic to Early Cretaceous strata}

A Volgian to Neocomian turbidite sequence is widespread on Stolbovoi, Malyi Lyakhov and Bol'shoi Lyakhov islands. The Volgian to Neocomian age of the sequence was reliably dated long ago on the basis of Buchia identified on Stolbovoi and Malyi Lyakhov islands. The situation is different for Bol'shoi Lyakhov Island. It was assigned to the Mesozoic by M. M. Ermolaev, and to the Late Proterozoic, to the Late Permian, to the Permian-Triassic by other authors. Samusin and Belousov (1985) provisionally dated a portion of the sequence as Late Jurassic, considering the major portion of the sequence, the Burustas formation, to be Permian in age, based on pollen and spore identifications. Today the Burustas formation is well studied and its late Jurassic to Neocomian age is reliably substantiated (Vinogradov et al., 1974; Samusin and Belousov, 1985; Kuzmichev et al., 2006). 


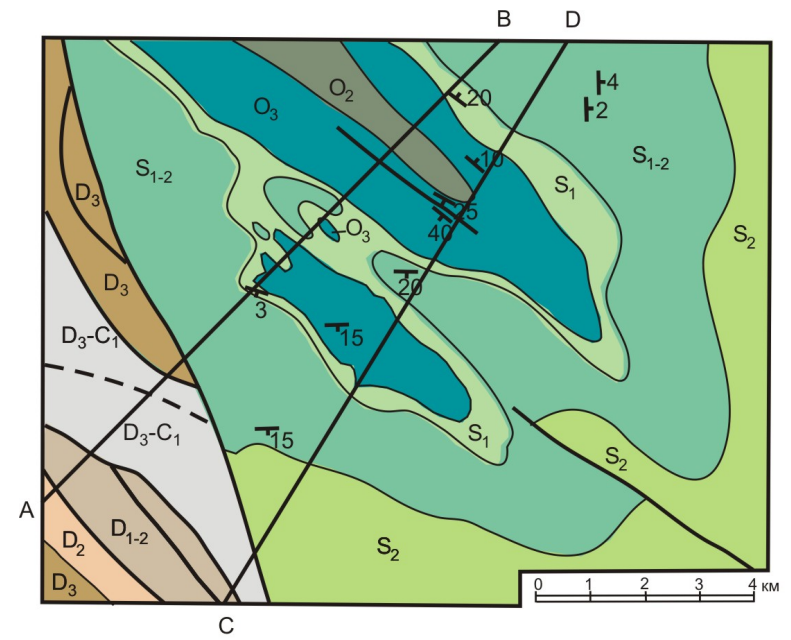

\begin{tabular}{|c|c|}
\hline $\mathrm{O}_{2}$ & Middle Ordovician \\
\hline $\mathrm{O}_{3}$ & Upper Ordovician \\
\hline $\mathrm{S}_{1}$ & Lower Silurian \\
\hline$S_{1-2}$ & Lower-Upper Silurian \\
\hline $\mathrm{S}_{2}$ & Upper Silurian \\
\hline$D_{1-2}$ & Lower-Middle Devonian \\
\hline $\mathrm{D}_{2}$ & Middle Devonian \\
\hline $\mathrm{D}_{3}$ & Upper Devonian \\
\hline $\mathrm{D}_{3}-\mathrm{C}_{1}$ & $\begin{array}{l}\text { Upper Devonian-Lower } \\
\text { Carboniferous }\end{array}$ \\
\hline & Faults \\
\hline$f_{10}$ & Bedding attitude \\
\hline
\end{tabular}

Fig. 10. Second order folds. Chokur anticlinorium. See location on Fig. 1.

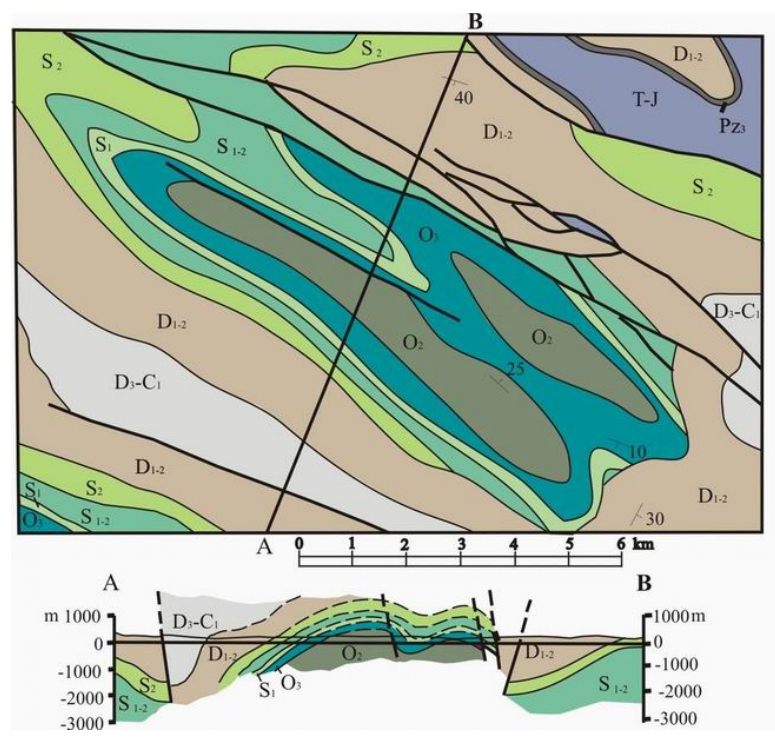

\begin{tabular}{|c|c|}
\hline T-J & Triassic - Jurassic \\
\hline $\mathrm{Pz}$ & Upper Paleozoic \\
\hline$D_{3}-C_{1}$ & Upper Devonian - Lower Carboniferous \\
\hline $\mathrm{D}_{1.2}$ & Lower-Middle Devonian \\
\hline $\mathrm{S}_{2}$ & Upper Silurian \\
\hline $\mathrm{S}_{1.2}$ & Lower-Upper Silurian \\
\hline $\mathrm{S}_{\mathrm{I}}$ & Lower Silurian \\
\hline $\mathrm{O}$ & Upper Ordovician \\
\hline$\overline{\mathrm{O}_{2}}$ & Middle Ordovician \\
\hline 7 & Faults \\
\hline
\end{tabular}

Fig. 11. Second order folds, Chokur anticlinorium. See location on Fig. 1.

The strata on Bol'shoi Lyakhov Island are graded bedded sandstone, siltstone, and phyllite. Their thickness varies from 0.5-1 $\mathrm{m}$ to 10-20 $\mathrm{m}$ (Samusin and Belousov, 1985). Individual sandstone packages are 50-70 m thick. Phyllite packages are built of Bouma sequences the thickness of which varies from centimeters up to meters. Convoluted bedding is common. There are rare, centimeters thick siltstone and slate interbeds within the sandstone packages. Bouma sequences built of sandstone, siltstone and phyllite are typical of the Burustas formation. Ripple- and crossbedding were reported. These provide evidence for a tidal depositional environment no deeper than storm wave base. Thick sandstone layers are believed to be products of dense grain flows. Sedimentary features are indicative of a shelf basin that filled with 

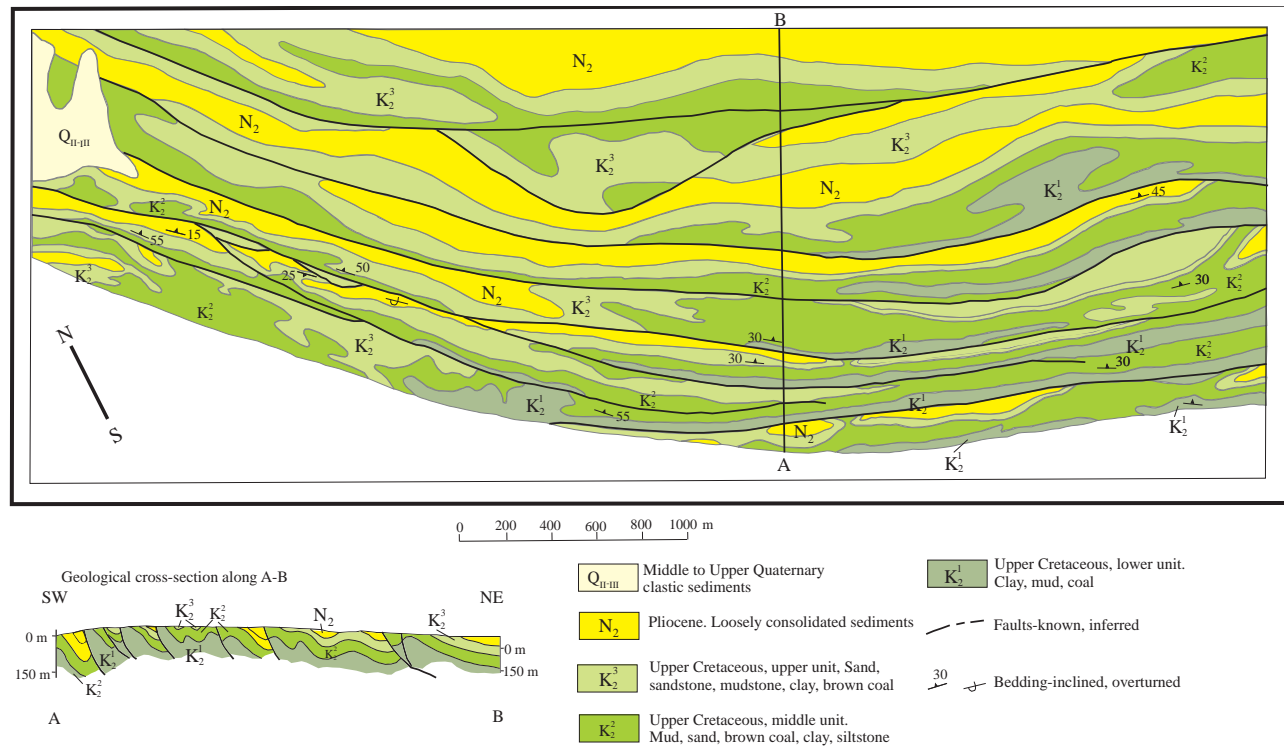

Fig. 12. Geological map and a cross section of the Utes Derevyannykh Gor site, Novaya Sibir' Island (Kos'ko and Trufanov, 2002). See location site 12 on Fig. 1.

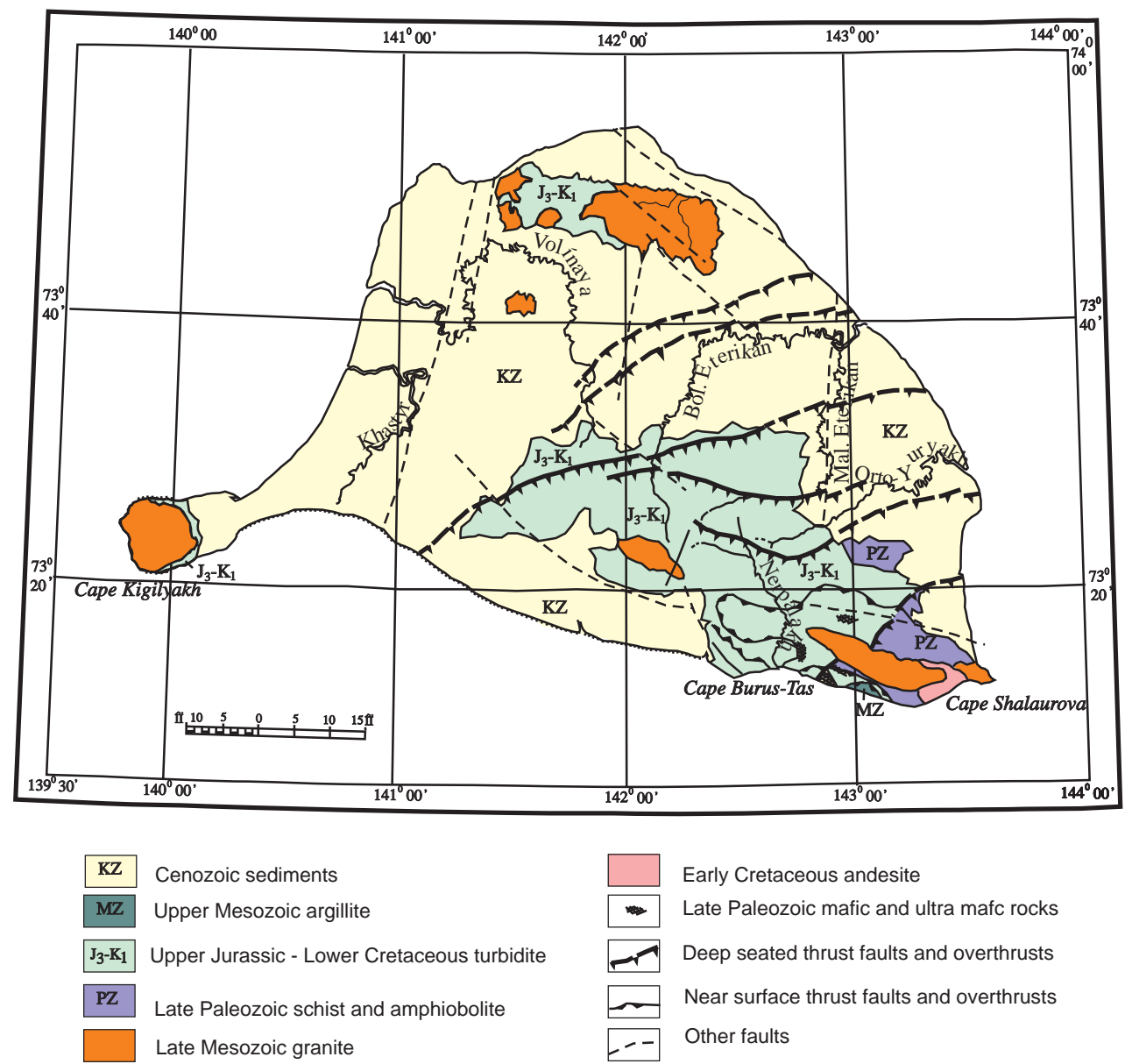

Fig. 13. Geologic map of Bol'shoi Lyakhov Island. Amended from Dorofeev et al. (1999) and Lopatin (1999). 


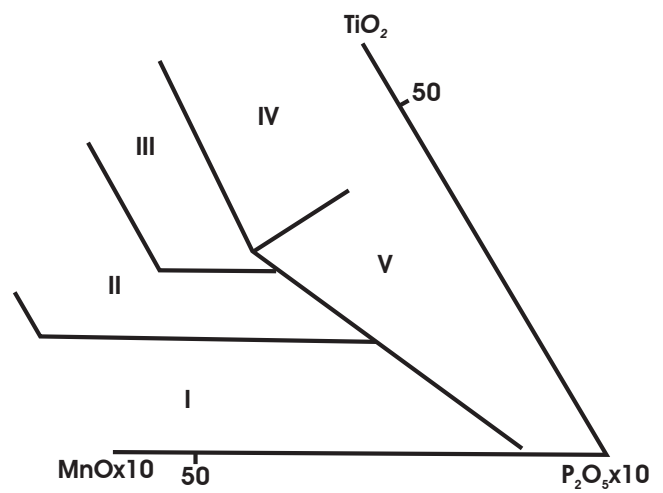

Fig. 14. Late Paleozoic pillow basalt, Mullen diagram (Mullen, 1983; Lopatin, 1999). I - calc-alkaline island arc and continental rift basalt, II - island arch tholeiite, III - MORB and marginal seas basalt, IV - ocean islands tholeiite, $\mathrm{V}$ - ocean islands alkaline basalt.

clastic matter shed from a nearby upland area. The depth of the depositional basin was estimated based on the presence of thick packages of poorly sorted silt/sandstone with storm type bedding. The above features are characteristic of a deep shelf environment (Kuzmichev et al., 2006).

The sandstones are immature, being composed of rock clasts, feldspar, quartz and clastic muscovite. There are abundant ore minerals at the base of sandstone beds. Products of the erosion of metamorphic rocks, granite, quartz veins and volcanic rocks are distinguishable among the clasts in the quartz sandstone. Feldspars are acidic plagioclase from volcanic rocks and granite. The presence of pargasite indicates the metamorphic source rocks, and the presence of high chromium chlorite is indicative of metamorphosed ultramafic source rocks. Rock clasts are mostly acidic, intermediate with rare mafic volcanics. In addition there are chert, slate, carbonates, chlorite-sericite schist, and quartzite clasts. Accessory minerals are zircon, apatite and rutile, variable in the degree of rounding and crystal peculiarities.

The major provenance area was most likely the western extremity of Anyui-Svyatoi Nos Arc, whose volcanic rocks outcrop in the Svyatoi Nos Point area on the mainland close to Bol'shoi Lyakhov Island. The late Jurassic commencement of the turbidites is evidenced by fission track dating of the youngest least rounded grains of the accessory zircon population $163.7 \pm 9.3,159.0 \pm 23.8$ and $119.6 \pm 14.5 \mathrm{Ma}$. Two first numbers are Middle to Late Jurassic, the last one reflects imposed heating caused by emplacement of Early Cretaceous granite (Kuzmichev et al., 2006). A rigid block with a sedimentary cover related to the present day Anjou islands is another possible provenance area. Repeatedly deposited well rounded zircons, metamorphic and granite clasts were shed from there. Ultramafic rocks and amphibolites similar to those exposed on Bol'shoi Lyakhov Island present a third source for the clastic material of the flysch sequence.

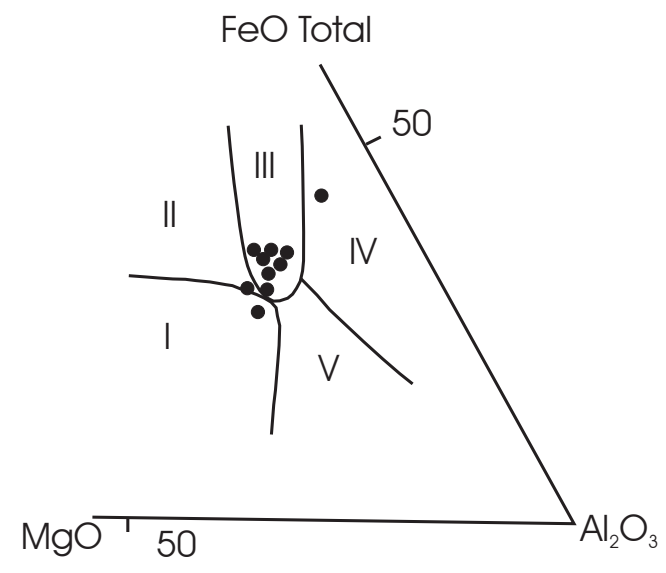

Fig. 15. Late Paleozoic pillow basalt, Pearce diagram (Pearce and Cann, 1973; Lopatin, 1999). I - MORB, II - ocean islands basalt, III - continental rift basalt, IV - ocean islands basalt in spreading zones, $\mathrm{V}-$ island arc basalt.

So the lower age limit of the turbidite sequence is close to the Middle-Late Jurassic boundary. The upper age limit is the emplacement in the Aptian of granite massifs hosted by the flysch. So the age of the sequence is late JurassicNeocomian. Late Proterozoic acritarchs as well as Late Paleozoic miospores were transported to the basin either along with clastic material or collected from not yet identified tectonic wedges of older rocks.

The sequence is intensely faulted and folded, and the assessment of the thickness is difficult. It is estimated as $1300 \mathrm{~m}$ (Samusin and Belousov, 1985).

Late Jurassic-Early Cretaceous strata on Stolbovoi and Malyi Lyakhov islands are alternating siltstone - argillite and mostly sandstone units rhythmically bedded with fossil Oxfordian to Valanginian Buchia. The thickness of the strata is approximately $1100 \mathrm{~m}$ in a composite section. Soft sediment slump structures on Stolbovoi Island are directed northeast downslope. Signs of near bottom contour currents were reported (Vinogradov and Yavshitz, 1975; Drachev, 1989).

\section{Early Cretaceous granites}

Granite emplacement was very intense in the Lyakhov Islands area during the Early Cretaceous. Granite, granodiorite, and quartz diorite massifs are exposed on Bol'shoi Lyakhov Island and are supposed to be present offshore north of Bol'shoi Lyakhov Island towards the Anjou Islands based on the interpretation of the potential field maps, and with less confidence to the northwest towards Bel'kovsky Island (Dorofeev et al., 1999; Lopatin, 1999). The massifs are up to $100-140 \mathrm{~km}^{2}$. They are isometric and elongated and thought to be controlled by major faults. The contacts are either steep or gently dipping beneath the host rocks. The emplacement of andesite-porphyric diorite preceded granite intrusion on southeast Bol'shoi Lyakhov Island. These intermediate com- 
position rocks rim the southeast extremity of the Emiytas massif. The andesite-diorite is either the first phase of the Emiytas intrusion, or an outlier of the Anuyi-Svyatoi Nos volcanic arc, positioned on the mainland and offshore south of the Bol'shoi Lyakhov Island.

Three groups of massifs are distinguished. The first one is composed of hornblende-biotite granodiorite with subordinate quartz diorite, porphyric diorite, and granite. These rocks have both transitional and eruptive contacts. The largest of the massifs of this group are located on southeast Bol'shoi Lyakhov Island.

The second group comprises massifs in northern Bol'shoi Lyakhov Island. The massifs are biotite granite, granodiorite, porphyric granite and porphyric granodiorite that suffered intense post-magmatic alterations and are remarkable for wide pneumatolythic-hydrothermal zones in bordering host rocks.

The third group is Kigilyakh massif on the southwest end of Bol'shoi Lykhov Island and the terminal phase of the Emiytas massif on southeast Bol'shoi Lykhov Island. They are composed of homogeneous biotite and biotite-muscovite alkaline granite with high tin content.

The intrusions are inferred to be hypabyssal from the mineral composition, structure, texture, scale and character of late and post magmatic phenomena. They are compatible with the granitoid intrusions of the Verkhoyansk and Polousny regions with respect to their composition and structural position.

An Aptian age has been determined radiometrically. The $\mathrm{U}-\mathrm{Pb}$ isochron age of zircons from the north Lyakhov granite is $118.9 \pm 0.42 \mathrm{Ma}$ (Dorofeev et al., 1999), from the Emiytas massif is $120 \pm 1.7 \mathrm{Ma}$ (A. P. Chukhonin, VSEGEI, written communication, 1993); K-Ar dating of biotite from different massifs is $118 \pm 6,120 \pm 5,119 \pm 5,122 \pm 5,120 \pm 6$, $122 \pm 7 \mathrm{Ma}$, from microcline $-112 \pm 5,114 \pm 6 \mathrm{Ma}$ (Dorofeev et al., 1999); 40Ar/39Ar age is $114.4 \pm 0.5 \mathrm{Ma}$ (Layer et al., 2001). The Diorite-granodiorite massifs were emplaced earlier than the rest of the granitoid massifs as deduced from the observed eruptive relationships.

\section{Tertiary strata}

The Tertiary sequence was divided into units similar to those on the Anjou Islands: Paleocene-Eocene, Upper OligoceneMiocene, Pliocene-Eopleistocene. The sediments are mostly mud, silt and sand with minor grit and pebble. Disconformities were documented at the boundaries of the units and within them (Kos'ko and Trufanov, 2002). Unlike the Anjou Islands there are no normal marine sediments here. Weathering profiles were observed at the base of the Cenozoic strata. The total thickness of the strata is approximately $200 \mathrm{~m}$.

\section{Structure and tectonics}

Fold and thrust imbricate structures are mapped on southern Bol'shoi Lyakhov Island. North-northwest vergent thrusts transect the Island and project offshore. The thrusts are well manifested in the magnetic field because they are accompanied by highly magnetic rocks. The thrusts dip southward and south-eastward at angles $30^{\circ}-50^{\circ}$ according to interpretation of the anomalous magnetic field performed by V. Verba, written communication, 1993.

Tectonic sheets were described (Drachev, 1989; Drachev and Savostin, 1993) along the south coast east of Burustas Cape. The following succession was discovered starting from the top: $1-$ a $50 \mathrm{~m}$ thick sheet of black argillite and clay presumably of Late Mesozoic age; 2 - turbidites of the Burustas formation; 3 - pillow basalt 200-300 m thick; 4 - tectonized ultramafics, the base of the sheet is not exposed; 5 - orthoamphibolite in a para-autochthonous position. The thrust faults bounding the sheets are folded. Folds are $10-15 \mathrm{~m}$ wide, hinges dip southeast at angles $20^{\circ}-30^{\circ}$. The sheets are intensely deformed. Detachment folds, overturned and steeply dipping layers are observed. Detachment folds were formed as a result of north-south directed compression. The age of the deformation is Early Cretaceous. Late Jurassic to Neocomian strata are folded and thrust, and Early Cretaceous granites also cut the thrusts. A series of tectonic sheets composed of mafic and ultramafic rocks thrust northwest over Burustas sandstones and phyllites which in their turn were thrust over ultramafics have been reported by Kuzmichev et al. (2005).

Open folds of Jurassic-Early Cretaceous strata are characteristic of Stolbovoi and Malyi Lyakhov islands. The folds strike northwest on Stolbovoi Island and east-west on Malyi Lyakhov Island. Limbs dip at angles of $15-20^{\circ}$ in most cases and up to $40^{\circ}$ on the south limbs of anticlines on Malyi Lyakhov Island.

Late Jurassic-Early Cretaceous turbidites filled a trough in the zone of late Cimmerian deformation. The Cimmerian trough continues east-southeast to Chukotka. The deformation was initiated by collision along the South Anyui suture and prograded north. The tectonic structure on Bol'shoi Lyakhov Island is that of an imbricate fold and thrust belt and Stolbovoi and Malyi Lyakhov islands show moderately intense folding. The sedimentary environment was relatively calm on the north side compared to that on the south. Benthic fauna could live in the north while active hydrodynamics and abundant clastic sedimentation prohibited benthic fauna settling on the south. Further north on Kotel'ny Island Jurassic strata are very poor in coarse clastic material.

The emplacement and evolution of the trough is a component of the evolution of the Late Jurassic-Early Cretaceous Anyui-Lyakhov fold system. The trough closed after magmatic activity ceased within the neighboring volcanic arc. The trough is an inner structure of the Late Cimmerian orogeny separating an outer relatively stable northern block from mobile regions to the south.

The southeast part of Bol'shoi Lyakhov Island was located within a major suture that extends all the way to Chukotka. Deep seated thrust faults related to the suture are mappable here based on the character of anomalous gravity and mag- 
netic fields. The suture displays imbricate structure comprising wedges and sheets built of rocks variable in age and composition including unevenly metamorphosed ophiolite sequences and glaucophane schist (Drachev, 1989; Drachev and Savostin, 1993; Kuzmichev et al., 2005). The tectonic activity of the suture terminated in Early Cretaceous as documented by the emplacement of granites (Dorofeev et al, 1999).

\section{Discussion and conclusions}

Knowledge of the geology of the New Siberian Islands is required to interpret anomalous gravity and magnetic field maps and Multi-Channel Seismic lines near the islands and in the more distant offshore. Improved geologic information has allowed us to outline major tectonic blocks and terranes to the east of the Laptev Sea, and for the western part of the East Siberian Sea shelf. It also allowed inferences to be drawn about their ages, structural styles and composition (Kos'ko et al., 1998; Kos'ko, 2007).

Geology of the New Siberian Islands supports the circum Arctic Phanerozoic fold belt concept (Egiazarov, 1977; Zhamoida et al., 1989). The belt comprises Caledonian, Ellesmerian, Early Cimmerian and Late Cimmerian fold systems, manifested in many places on the mainland and on islands around the Arctic Ocean. Early Paleozoic sequences on the De Long Islands belong to the Caledonian fold system along with Axel Heiberg and northern Ellesmere Island in the Arctic Canada, Spitzbergen, and northern Norwegian Caledonides. Metamorphic and granite clasts present on Henrietta and Jeannette islands indicate a provenance area with exposed crystalline basement not far away. It could be a margin of the Hyperborean Platform, now destroyed by the evolving Arctic Basins, or ancient terranes within Caledonian mobile belt. The Anjou and Lyakhov Islands are undoubtedly the westernmost extremity of the Late Cimmerian fold system traced here from the Brooks Range in Alaska through Chukotka. The fold system comprises South Anyui ophiolite suture and pre-collisional trough exposed on the Lyakhov Islands, and moderately folded and faulted Paleozoic and Mesozoic sequences of its outer zone known on Kotel'ny Island. The South Anyui ophiolite suture terminates within the Bol'shoi Lyakhov area according to the anomalous magnetic field pattern. The presence of relict Caledonian units reworked in the course of the Late Cimmerian tectonism on Bol'shoi Lyakhov Island is very hypothetical but not out of the question. It is questionable whether evidence for Ellesmerian and Early Cimmerian orogeny will be found on the New Siberian Islands, although they may project into the East Siberian Sea shelf from the east. The thick Devonian turbidite unit on Wrangel Island (Kos'ko et al., 1993) and Middle to Upper Devonian marginal sea sediments and volcanics on Chukotka (Natal'in et al., 1999) document rem- nants of an Ellesmerian fold system within the Late Cimmerian fold system on the east margin of the East Siberian Sea.

There is ongoing discussion of the overall East Arctic paleogeography, and at the present time there is little agreement as to which models are best. The New Siberian Islands are often referred to in the discussion (Miller et al., 2006; Lawer and Scotese, 1990; Lawer et al., 2002). A detailed discussion of the various paleogeographic models is beyond the scope of this review.

The sedimentary cover in the East Arctic Russian shelf comprises two structural stages (Gramberg et al., 2004). It is recognized that the structural stages correlate with the geology of the New Siberian Islands. Dating of the upper structural stage and constituent offshore seismic units was based in large part on the structural and stratigraphic relationships between Late Mesozoic and Cenozoic units in the Anjou Islands (Franke et al., 2001, 2004; Franke and Hinz, 1999; Hinz, 1997; Kos'ko, 2005; Kos'ko and Trufanov, 2002). The Laptev Sea-western East Siberian Sea seismostratigraphic model for the upper structural stage fits in general with the major unconformities known in the American part of the Chukchi Sea (Sherwood et al., 1998, 2002; Thurston and Theiss, 1987). The lowermost regional reflector LS1/ESS1 (Franke et al., 2001, 2004; Franke and Hinz, 1999; Hinz, 1997) which is an acoustic basement for the Laptev and western East Siberian Seas correlates with equal confidence with the Aptian unconformity and pre-Cenomanian disconformity on the Anjou Islands, and to the ubiquitous erosional and weathered surface close to the Cretaceous-Paleocene boundary. On the eastern Chuckhi Sea shelf the base of the upper structural stage can be related either to the Lower Cretaceous Unconformity (LCU) or the Barremian Unconformity (BU). Dating of the LCU varies from one well to another as follows: Late Berriasian, Valaginian-Hauterivian boundary, Early Hauterivian, Late Barremian. The Barremian unconformity was placed within the Barremian and Early Aptian stages. There is a Middle Barremian Unconformity (MBU) which is a hiatus embracing the Late Cretaceous. So the regional unconformity seen throughout the East Arctic Eurasian shelf which is interpreted as the base of the upper structural stage of the sedimentary cover, varies in age within the middle Cretaceous and Early Paleogene. The LS2/ESS2 regional reflector in the Laptev Sea and western East Siberian Sea correlates with the base of Upper Oligocene-Miocene strata on the New Siberian Islands. A Lower Oligocene hiatus was reported as well from POPCORN well, Eastern Chukchi Sea (Sherwood et al., 1998, 2002).

Interpreting Cretaceous and Miocene-Quaternary volcanism on the De Long Islands as a surface manifestation of a mantle plume, the latter being well substantiated by field and laboratory research (Silantyev et al., 2004) raises problems. It is not clear, whether there were two plumes: an old one of Cretaceous age, and a younger one in Miocene-Quaternary time, or there is one plume which started in the Middle Cretaceous and perhaps still exists. The first option is in agreement 
with the lack of evidence for volcanic activity between Late Cretaceous and Late Miocene time, and differences in composition of parental melts of the Cretaceous on one hand and the Miocene-Quaternary volcanics on the other. The concept of one long-lived plume needs to be tested by seeking evidence of plume activity which may be obscured by seawater and bottom sediments. Without that evidence we have to accept that there were two magmatic events separated by a $100 \mathrm{Ma}$ interlude, which is much longer than the events themselves. The differences in the parental melts within one long term plume hypothesis are understandable as a result of progressive differentiation stages of an original melt ascending from the mantle. The De Long plumes are components of a hierarchy of plumes subordinate to a global scale Arctic superplume.

A large portion of the above conclusions and interpretations are still highly hypothetical, and will remain that way until more field observations supported by an advanced laboratory research is performed.

Acknowledgements. The authors thank David Stone for the invitation to write the above review for this volume. We are honored to be in a team of geoscientists who remember and give credit to Leonid Parfenov. We thank Kazua Fujita following whose kind critical comments we have substantially reworked the paper. Our thanks are to be extended to A. Kuzmichev and to S. Drachev for discussions which were very productive. We thank Olga Vinogradova who assisted us for many years both in the field and in the office.

\section{References}

Bogdanovsky, O. G., Mineev, S. D., Assonov, S. S., Silantiev, S. A., Karpenko, S. F. Shukulyukov, Yu. A., and Savostin, L. A.: Magmatism of De Long Archipelago (East Arctic). Isotope geochemistry and geochronology, Geokhimia, 1, 47-55, 1992 (in Russian).

Dorofeev, V. K., Blagoveschensky, M. G., Smirnov, A. N., and Ushakov, V. I.: New Siberian Islands, Geology and minerageny, VNIIOkeangeologia, Saint-Petersburg, 130 pp., 1999 (in Russian).

Drachev, S. S.: Tectonics and Meso-Cenozoic geodynamics of the New Siberian Islands region, Ph.D. thesis, Moscow State University, 19 pp., 1989 (in Russian).

Drachev, S. S. and Savostin, L. A.: Ophiolites of the Bol'shoi Lyakhov Island (New Siberian Islands), Geotektonika, 3, 98107, 1993 (in Russian).

Egiazarov, B. Kh., Ermakov, B. V., Anikeeva, L. I., Romanovich, B. S., Pol'kin, Ya. I., Atltsov, I. P., Demenitskaya, R. M., Grachev, A. F., Karasik, A. M., Kiselev, Yu. G., Andreev, S. I., and Kos'ko, M. K.: Tectonica of the North Polar region of the Earth, Explanatory note to the Tectonic Map of the North Polar region of the Earth scale 1:5000000, NIIGA, Leningrad, 200 pp., 1977 (in Russian).

Egorov, A. Yu. and Surmilova, E. P.: State Geological Map of the Russian Federation, Scale 1:1 000 000, Quadrangle S-50-52,
Bykovsky, Explanatory note, Kartfabrika VSEGEI press, SaintPetersburg, 189 pp., 2001 (in Russian).

Fedorov, P. I., Flerov, G. B., and Golobin, D. I.: New data on the age and composition of volcanic rocks on the Bennett island (East Arctic), Dokl. Akad. Nauk+, 400(5), 666-670, 2005 (in Russian).

Franke, D. and Hinz, K. (Coordinator): Final Report, the Laptev Sea BGR project. Neotectonic studies in the Laptev Sea and East Siberian Sea, and NE Siberian borderland including seismological data, Project No 03G0529A, 122 pp., 1999.

Franke, D., Hinz, K., and Reichert, C.: Geology of East Siberian Sea, Russian Arctic, from seismic images: Structures, evolution, and the implications for the evolution of the Arctic Ocean Basin, J. Geophys. Res., 109, B07106, doi:10.1029/2003JB002687, 2004.

Franke, D., Hinz, K., and Oncken, O.: The Laptev Sea Rift, Mar. Petrol. Geol., 18, 1083-1127, 2001.

Gramberg, I. S.: Paleohydrochemistry of the terrigenous deposits, Nedra, 170 pp., 1973 (in Russian).

Gramberg, I. S., Ivanov, V. L., and Pogrebitsky, Yu. Ye. (Eds.): Geology and mineral resources of Russia, Vol. 5, Arctic and Far East Seas, Book 1, Arctic Seas, VSEGEI Press, Saint-Petersburg, 468 pp., 2004 (in Russian).

Gusev, B. V. and Rakhin, V. A.: Geologic results of the paleomagnetic research on the New Siberian Islands, in: Problems of geophysical research in the Polar Regions of the Earth, NIIGA, Leningrad, 24-34, 1977 (in Russian).

Hinz, K. (Coordinator): Cruise Report, Marine Seismic Measurements and Geoscientific Studies on the Shelf and Slope of the Laptev Sea and East Siberian Sea/Arctic with M. V. Academic Lazarev, I. B. Kaptain Dranitsin, 23. August - 08. October 1997, Hannover, Germany, Bundesanstalt für Geowissenschaften und Rohstoffe, Part 1, 161 pp., Part II, 52 pp., 1997.

Kaplan, A. A., Coppland, P., Bro, E. G., Korago, E. A., Proskurnin, V. F., Vinogradov, V. A., Vrolijk, P. J., and Walker, J. D: New radoiometric ages of igneous and metamorphic rocks from the Russian Arctic, VNIGRI/AAPG regional international conference, July 15-18, Saint-Petersburg, Russia, 06-2, 2001.

Kos'ko, M. K.: Stratification of the sedimentary cover of the East Arctic shelf of Russia,in: Proceedings of the 2nd International Conference "Geodynamics of the oil and gas bearing basins" Moscow, October 19-21, 2004, Moscow, 98-110, 2005 (in Russian).

Kos'ko, M. K.: Structural and facies zonation of the Ordovicianmiddle Devonian carbonate sequence on the Anjou Islands, Tectonics of the Arctic. Fold basement of the shelf sedimentary basins, NIIGA, Leningrad, 56-87, 1977 (in Russian).

Kos'ko, M. K.: Terranes of the East Arctic Russian shelf, Dokl. Akad. Nauk+, 213(1), 71-74, 2007 (in Russian).

Kos'ko, M. K., Bondarenko, N. S., and Nepomiluev, V. F.: State Geological Map of the USSR, Scale 1:200 000 (New Siberian Islands), Quadrangles T0-54-XXXI, XXXII, XXXIII; S-53-IV, V, VI; S-54-I, II, III, S-54-VII, VIII, IX, XIII, XIV, XV, Explanatory Note, "Sevmorgeologia", 162 pp., 1985 (in Russian).

Kos'ko, M. K., Cecile, M. P., Korago, E. A., Lane, L. S., Musatov, E. E., Piskarev, A. L., Suprunenko, O. I., Ustinov, N. V., and Verba, V. V.: Tectonic Basement of the Eurasian Arctic Shelf: Age and Some Aspects of Evolution, Polarforschung, 68, 275281, 2000. 
Kos'ko, M. K. and Trufanov, G. V.: Middle Cretaceous to Eopleistocene sequences on the New Siberian Islands: an approach to interpret offshore seismic, Mar. Petrol. Geol., 19, 901-919, 2002.

Kos'ko, M. K., Cecile, M. P., Harrison, J. C., Ganelin, V. G., Khandoshko, N. V., and Lopatin, B. G.: Geology of Wrangel Island, between Chukchi and East Siberian Seas, Northeastern Russia, Geological Survey of Canada, Ottawa, Bulletin, 461, 101 pp., 1993.

Kuzmichev, A.: Subvolcanic dikes and peperites in western Bel'kov island - a backcountry of the Siberian Trap province on the New Siberian Islands, Norsk Geologiisk Forening, 2004.

Kuzmichev, A. B. and Goldyrev, A. E.: Permian-Triassic trap magmatism on Bel'kov island (New Siberian Islands), Geol. Geofiz., 48(2), 216-228, 2007 (in Russian).

Kuzmichev, A. B., Sklyarov, E. V., and Barash, I. G.: Pillow basalts and glaucophane schists on Bol'shoi Lyakhov Island (New Siberian Islands) fragments of lithosphere of the South Anyui paleo ocean, Geol. Geofiz., 46(12), 1367-1381, 2005 (in Russian).

Kuzmichev, A. B., Soloviev, A. V., Gonikberg, V. E., Shapiro, M. N., and Zamzhitsky, O. E.: Syncollisional Mesozoic terrigenous deposits, Bol'shoi Lyakhov Island (New Siberian Islands, Stratigrafia, geologicheskaya korrlelatsia, 14(1), 33-53, 2006 (in Russian).

Lawver, L. A., Grantz, A., and Gahagan L. M.: Plate kinematic evolution of the present Arctic region since the Ordovician, in: Tectonic Evolution of the Bering Shelf - Chukchi Sea - Arctic Margin and Adjacent Landmasses, edited by: Miller, E. L., Grantz, A., and Klemperer, S. L., Geological Society of America, Boulder, Colorado, Special Paper, 360, 333-358, 2002.

Lawver L. A. and Scotese, C. R.: A review of tectonic models for an evolution of the Canada Basin, in: The Geology of North America, volume L., The Arctic Ocean Region, edited by: Grantz, A., Johnson, L., and Sweeny, J. F., Geological Society of America, Boulder, Colorado, 593-618, 1990.

Layer, P. W., Newberry, R., Fujita, K., Parfenov, L., Trunilin, V., and Bakharev, A.: Tectonic setting of the plutonic belts of Yakutia, northeast Russia, based on ${ }^{39} \mathrm{Ar} /{ }^{40} \mathrm{Fr}$ geochronology and trace element geochemistry, Geology, 29(2), 167-170, 2001.

Layer, P., Parfenov, L. M., Surnin, A. A., and Timofeev, V. F.: First ${ }^{40} \mathrm{Ar} /{ }^{39}$ Ar datings of the magmatic and metamorphic rocks of the Verkhoyano-Kolyma Mesozoids, Dokl. Akad. Nauk+, 329(5), 621-624, 1993 (in Russian).

Layer, P. W., Vogel, T. A., Fujita, K., and Surnin, A. A.: Recent volcanism in Yakutia and the East Siberian Shelf, Russia, Implications for the NE Asia Cenozoic stress regime, EOS T. Am. Geophys. Un., 73, Fall meeting supplement, 563, 1992.

Lopatin, B. G. (Ed.): State Geological Map of the Russian Federation, Scale 1:1 000 000, Quadrangle S-53-55 - New Siberian Islands, Explanatory note, VSEGEI press, Saint-Petersburg, 208 pp., 1999 (in Russian).

Makeev, V. M., Davydov, V. K., and Ustritsky, V. I.: Discovery of middle Carboniferous deposits with tropic fauna on the De Long islands, in: Paleozoic stratigraphy and paleontology of the Arctic, Leningrad, "Sevvmorgeologia", 167-170, 1991 (in Russian).

Masurenkov, Yu. P. and Flerov, G. V.: Basalts of the Bennett Island in the Soviet Arctic, Vulkanologia b seismologia, 1, 36-53, 1989 (in Russian).
Miller, E. L., Toro, J., Gehrels, G., Amato, J. M., Prokopiev, A., Tuchkova, M. I., Akinin, V. V., Dumitru, T. A., Moore, A., and Cecile, M. P.: New insights into Arctic paleogeography and tectonics from $\mathrm{U}-\mathrm{Pb}$ detrital zircon geochronology, Tectonics, 25, TC3013, doi:10.1029/2005TC001830, 2006.

Miyashiro, A., Shido, F., and Ewing, M.: Crystallization and differentiation in abyssal tholeites and gabbro from mid-oceanic ridges, Earth Planet. Sci. Lett., 7(4), 361-365, 1970.

Mullen, E. D.: $\mathrm{MnO} / \mathrm{TiO}_{2} / \mathrm{P}_{2} \mathrm{O}_{5}$ : A minor element discriminant for basaltic rocks of oceanic environments and its implications for petrogenesis, Earth Planet. Sci. Lett., 62, 53-62, 1983.

Natal'in, B. A., Amato, J. M., Toro, J., and Wright, J. E.: Paleozoic rocks of northern Chukotka Peninsula, Russian Far East: Implications for the tectonics of the Arctic region, Tectonics, 18(6), 977-1003, 1999.

Pearce, J. A. and Cann, J. R.: Tectonic setting of basic volcanic rocks determined using trace element analyses, Earth Planet. Sci. Lett., 19, 290-300, 1973.

Prokopiev, A. V., Toro, J., Miller, E. L, Hourigen, G. K., Tarabukin, V. P., and Dumitru, T. A.: Style of deformation of Verkhoyansk fold and thrust sequence, Otechcstvennaya Geologia, 5, 47-51, 2001 (in Russian).

Samusin, A. I. and Belousov, K. N.: State Geological Map of the USSR, Scale 1:200000 (New Siberian Islands), Quadrangles S-53-XVI, XVII, XXII, XXIII; S-54-XIV, XV, XVI; S54-XX, XXI, XXII; S-54-XXIII, XXIV; S-54-XXVII, XXVIII; S-54-XXIX, XXX, Explanatory Note, Moscow, 129 pp., 1985 (in Russian).

Sherwood, K. W., Craig, J. D., Cooke, L. W., Lothamer, R. T., Johnson, P. P., Zerwick, S. A., Scerr, J., Herman, B., McLean, D., Haley, S., Larsen, J., Parker, J., Newman, R., Comer, C. D., Banet, S. M., Hurlburt, S. B., Sloan, P., Martin, G., and Horowitz, W. L.: Undiscovered Oil and Gas Resources, Alaska Federal Offshore, As of January 1995, edited by: Sherwood, K. W., US Department of the Interior Mineral Management Service, Alaska OCS Region, Anchorage, Alaska, (OCS Monograph MMS 98-0054), 382 pp., Appendices, 1998.

Sherwood, K. W., Johnson, P. P., Craig, J. D., Zerwick, S. A., Lothamer, R. T., Thurston, D. K., and Hurlbert, S. B.: Structure and Stratigraphy of the Hanna Trough, US Chukchi Shelf, Alaska, in: Tectonic Evolution of the Bering Shelf-Chukchi SeaArctic Margin and Adjacent Landmasses, edited by: Miller, E. L., Grantz, A., and Klemperer, S. L., The Geological Society of America, Boulder, CO, USA, Special Paper, 360, 39-66, 2002.

Silantiev, S. A., Bogdanovsky, O. G., Savostin, L. A., and Kononkova, N. N.: Magmatism of De Long Archipelago (East Arctic): Petrography and petrochemistry of extrusive rocks and associated xenoliths (Zhokhov and Vil'kitsky islands), Geokhimiya+, 2, 267-277, 1991 (in Russian).

Silantyev, S. A., Bogdanovskii, O. G., Fedorov, P. I., Karpenko, S. F., and Kostitsyn, Yu. A.: Intraplate magmatism of the De Long Islands: A response to the propagation of the ultraslow-spreading Gakkel Ridge into passive continental margin in the Laptev Sea, Russian Journal of Earth Sciences, 6(3), June 2004.

Sobolevskaya, R. F.: Ordovician and Silurian Graptolites on the New Siberian islands, in: Graptolites and Stratigraphy, Akademia Nauk Estonskoi SSR press, Tallinn, 202-209, 1976 (in Russian). 
Sokolov, S. D., Bondarenko, G. Ye., Morozov, O. L., Shekhovtsov, V. A., Glotov, S., Ganelin, A. V., an dKravchenko-Berezhnoy, I. R.: South Anyui suture, northeast Arctic Russia: Facts and Problems, in: Tectonic Evolution of the Bering Shelf - Chukchi Sea - Arctic Margin and Adjacent Landmasses, edited by: Miller, E. L., Grantz, A., and Klemperer, S. L., Geological Society of America, Boulder, Colorado, Special Paper, 360, 209-224, 2002.

Thurston, D. K. and Theiss, L. A.: Geologic report for the Chukchi planning area, Alaska, Regional geology, petroleum geology, and environmental geology, US Department of the Interior MMS, Alaska OSC Region, Anchorage, Alaska, 193 pp., 1987.

Trufanov, G. V., Belousov, K. N., and Nepomiluev, V. F.: State Geological Map of the USSR, Scale 1:200000 (New Siberian Islands), Quadrangles T-54-XXXIV, XXXV, XXXVI; T-56XXXIII; S-54-IV, V, VI, X, XI, XII; S-55-I, II, II, IV, V, VI, VII, VIII, IX, X, XI, XII; S-56-III, VII, Explanatory Note, Moscow, 106 pp., 1986 (in Russian).

Vinogradov, V. A., Dibner, A. F., and Samusin, A. I.: Discovery of the Permian strata on the Bol'shoi Lykhov Island, Dokl. Akad. Nauk+, 219(5), 1200-1202, 1974 (in Russian).
Vinogradov, V. A., Kameneva, G. I., and Yavshitz, G. P.: On the Hyperborean Platform with respect to the new data on the geology of the Henrietta Island, in: Tectonics of the Arctic, NIIGA, Leningrad, 1, 21-25, 1975 (in Russian).

Vinogradov, V. A. and Yavshitz, G. P.: Stratigraphy of the upper Jurassic and lower Cretaceous deposits on the north Stolbovoi Island, in: Geology and mineral resources of the New Siberian Islands and Wrangle Island, Leningrad, 38-42, 1975 (in Russian).

Vol'nov, D. A. and Sorokov, D. S.: The geology of the Bennett Island, in: Collection of papers on the geology and oil and gas resources of the Arctic, Gostoptekhizdat, Leningrad, 16, 5-18, 1961 (in Russian).

Vol'nov, D. A., Voitsekhovsky, V. N., Ivanov, O. N., Sorokov, D. S., and Yashin, D. S.: New Siberian Islands, in: Geology of the USSR, The Islands of the Soviet Arctic, Nedra, Moscow, 26, 324-374, 1970 (in Russian).

Zhamoida, A. I., Krasny, L. I., and Strel'nikov, S. I (Eds.): Geological structure and economic minerals of the USSR, Vol. 10, Geological structure and mineralogeny of the USSR, Book 1, Geological structure of the USSR, Ministry of geology of the USSR, Nedra, Leningrad, 352 pp., 1989 (in Russian). 